\title{
Impact of land use on juvenile densities of woody plants in a West African savanna
}

Received: 2016-11-15; revised: 2016-12-01; accepted: 2016-12-03

\author{
Katrin Jurisch $^{1 *}$, Markus Bernhardt-Römermann², Rüdiger Wittig ${ }^{3}$, Karen Hahn \\ ${ }^{1}$ Climate Alliance, European Secretariat, Galvanistr. 28, Frankfurt am Main, 60486 Germany \\ ${ }^{2}$ Institute of Ecology, Friedrich Schiller University of Jena, Dornburger Str. 159, 07743 Jena, Germany \\ ${ }^{3}$ Institute of Ecology, Evolution and Diversity, Goethe University Frankfurt am Main, Max-von-Laue Str. 13, 60438 Frank- \\ furt am Main, Germany \\ * Corresponding author; email: katrinju@gmx.de
}

\begin{abstract}
Summary: In West African savannas, human land use affects the density of woody species seedlings and saplings (juveniles) by altering the state of the physical, chemical, and biological characteristics of the land resulting in different land-cover types. We determined juvenile densities of 25 characteristic woody savanna species on non-arable sites, in fallows and in a protected area (in total 39 plots), and analyzed the influence of land use on juvenile densities. We further related the influence of land use on juvenile densities to 23 environmental parameters describing soil properties and vegetation structure. Soil acidity, particle size distribution of the soil, and vegetation structure differed between land-cover types. In terms of human impact, we detected five groups of species responding similarly to land use. Although we detected significant differences in soil properties, their direct effects on juvenile densities are less pronounced than their indirect effects. By altering the availability of resources, soil properties affect height and cover of all plants growing in the surrounding of a young woody plant, increasing the competition for light, water and nutrients during the establishment and initial growth. These effects are intensified by human land use and vary between land-cover types.
\end{abstract}

Key words: abundance, Benin, human impact, soil conditions, vegetation cover, vegetation height

\section{IMPACT DE L'UTILISATION DES TERRES SUR LES DENSITÉS JUVÉNILES DE PLANTES LIGNEUSES DANS UNE SAVANE D'AFRIQUE DE L'OUEST}

Résumé: Dans les savanes de l'Afrique de l'Ouest, l'occupation des sols affecte la densité des semis et des jeunes plants des espèces ligneuses par son influence sur les caractéristiques physiques, chimiques et biologiques des terres, ce qui entraîne de différents types de couvert végétal. Nous avons déterminé la densité juvénile de 25 espèces caractéristiques de savane ligneuse sur des sites non arables, en jachère et dans une aire protégée (au total 39 parcelles), et nous avons analysé l'influence de l'utilisation des terres sur les densités juvéniles. Nous avons également mis en rapport l'influence de l'utilisation des terres sur les densités juvéniles avec 23 paramètres environnementaux décrivant les propriétés du sol et la structure de la végétation. L'acidité du sol, la répartition granulométrique du sol et la structure de la végétation différaient selon les types de couvert végétal. En termes d'impact humain, nous avons détecté cinq groupes d'espèces répondant de manière similaire à l'utilisation des terres. Bien que nous ayons détecté des différences significatives dans les propriétés du sol, leurs effets directs sur les densités juvéniles sont moins prononcés que leurs effets indirects. En modifiant la disponibilité des ressources, les propriétés du sol affectent la hauteur et la couverture de toutes les plantes qui poussent à l'entour d'une jeune plante ligneuse, augmentant la concurrence pour la lumière, l'eau et les nutriments pendant l'établissement et la croissance initiale. Ces effets sont intensifiés par l'utilisation des sols et varient selon les types de couvert végétal.

Mots clés: abondance, Bénin, impact humain, conditions du sol, couverture végétale, hauteur de végétation

\section{AUSWIRKUNGEN DER LANDNUTZUNG AUF DAS VORKOMMEN VON GEHÖLZJUNGWUCHS IN EINER WESTAFRI- KANISCHEN SAVANNE}

Zusammenfassung: In den westafrikanischen Savannen beeinflusst die Landnutzung die Dichte der Gehölzkeimlinge und Jungpflanzen, indem sie physikalische, chemische und biologische Eigenschaften der Flächen verändert und zu unterschiedlichen Landnutzungstypen führt. Es wurde der Einfluss der Landnutzung auf die Individuendichte von Keimlingen und Jungpflanzen von 25 charakteristischen Savannengehölzarten auf nicht kultivierten Flächen, in Brachen und in einem Schutzgebiet (insgesamt 39 Parzellen) untersucht. Darüber hinaus haben wir den Einfluss der Landnutzung auf die Individuendichte mit 23 Umweltparameter in Beziehung gesetzt, die die Bodeneigenschaften und die Vegetationsstruktur beschreiben. Die Bodensäure, die Korngrößenzusammensetzung des Bodens und die Vegetationsstruktur unterscheiden sich zwischen den Landnutzungstypen. In Bezug auf den menschlichen Einfluss, ließen sich fünf Artengruppen unterscheiden, die jeweils ähnlich auf die Landnutzung reagieren. Obwohl wir signifikante Unterschiede in den Bodeneigenschaften festgestellt haben, sind ihre direkten Auswirkungen auf die Individuendichte der Gehölzkeimlinge und Jungpflanzen weniger ausgeprägt als ihre indirekten Effekte. Die Bodeneigenschaften verändern die Verfügbarkeit von Ressourcen und beeinflussen darüber die Höhe und Bedeckung der Pflanzen, die im Umfeld des Gehölzjungwuchses wachsen. Dadurch erhöht sich die Konkurrenz um Licht, Wasser und Nährstoffe für den Jungwuchs in seiner Etablierungs- und anfänglichen Wachstumsphase. Diese Effekte werden durch die Landnutzung verstärkt und variieren zwischen Landnutzungstypen.

Schlagworte: Abundanz, Benin, menschlicher Einfluss, Bodenbedingungen, Vegetationsbedeckung, Vegetationshöhe 


\section{INTRODUCTION}

The savanna regions of West Africa are frequently affected by human-induced disturbances. Aside from agricultural activities (crop production and animal husbandry), the harvesting of timber and non-timber forest products affects savanna vegetation (see, e.g., WiTTIG et al. 2002). During recent decades, social and economic conditions have changed dramatically (DescroIX et al. 2009, NorRIs et al. 2010, OUEDRAOGO et al. 2010), causing habitat loss, the shortening of fallow periods, over-grazing and the removal and vitality impairment of reproductive individuals of trees and shrubs (e.g. by harvesting of non-timber forest products). JURISCH et al. (2012) showed that the population structure of some woody plant populations, especially tree populations, is strongly affected by human-induced disturbances, while others perform quite well under the current land use system, mainly shrub species. For many tree species, reproductive individuals of the sub-adult and adult stage were missing. This can reduce the availability of their seeds and may thereby lead to a lack of regeneration and a low density of their juveniles (young, immature individuals) (PLUMPTRE 1995, Makana \& Thomas 2004, McLaren et al. 2005). This development becomes more pronounced as due to increased human pressure, habitats suitable for juvenile establishment are becoming fewer. In the long run, the observed results may have implications for local woody species composition.

In particular, the seedling and sapling stages are usually a critical phase in the regeneration of woody species, as for plants at these stages the risk of abiotic stress caused by human-induced disturbances (e.g. fire and livestock grazing) as well as soil conditions and biological interactions (intra- and interspecific plant competition) is very high (АВRAHAMSON 1980, BOND 2008, JURISCH et al. 2012, 2013; PRIOR et al. 2010, ZIDA 2007). Habitats like less disturbed termite mounds show a consistently higher species richness and diversity of juvenile woody plants than their surrounding savannas (ERPENBACH et al. 2014). Consequently, seedlings must quickly develop an effective root system to allocate and store nutrients and to gain access to water, which enhances the individual's ability to tolerate and be resilient to disturbances (Grossnickle 2005, HofFMAN et al. 2004, Wigley et al. 2009). The topsoil properties are important for the establishment of young plants, as most of their root biomass is located close to the surface (JEFFREY 1987, KAONGA \& BAYLISS-SMith 2012, KNOOP \& WALKER 1985, WeLtZIN \& MCPHERSON 1997). In situ experimental studies from semi-arid South Africa have revealed that herbaceous competition was intensified under nutrient-rich conditions by enhancing growth rates of grasses. This may lead to a decrease in seedling densities, as well as to changes in growth rates, morphology and resource allocation (BUSH \& VAN AUKen 1995, KraAiJ et al. 2006, Staver et al. 2009, van AuKEN \& BUSH 1997, VAN DER WAAL et al. 2009).

The impact of human land-use on the density of seedlings and saplings of woody plants in West African savannas has been determined so far only for single species in comparative studies between protected and non-protected areas (Djossa et al. 2008, PARe et al. 2009, Schumann et al. 2011) and in relation to management practices (DHILLION \& Gustad 2004, Kouami et al. 2009, Ky-Dembele et al. 2007).
These studies generally report higher seedling and sapling densities in non-protected areas with moderate human disturbance compared to protected sites. Prescribed fire, moderate livestock grazing and selective removal of trees were found to have an indirect positive effect on seedling and sapling densities and growth by reducing vegetation cover and thus, reducing intra- and interspecific plant competition for light, water and nutrients (DHILLON \& GusTad 2004, Djossa et al. 2008, Kelly et al. 2004, WalKer et al. 1981). By contrast, some studies detected that fire and browsing may suppress the recruitment of young plants by removing above-ground plant parts or the entire plant. This is more pronounced in dry climate with low rainfall causing greater water stress and thus, limiting the regeneration potential of plants (FATUBARIN 1987, Gijsbers et al. 1994, KesSLER \& Breman 1991, Menaut 1983, Zida et al. 2007, 2008). Aside from the direct damage of the plant, grazing can reduce fire frequency and intensity due to the reduction of the amount of inflammable biomass (WALKER et al. 1981, JEFFREY 1987, ARCHER 1995) and may change the availability of soil nutrients and structural properties of soil by deposition of dung and the impact of trampling (BRESHEARS et al. 1997, Davenport et al. 1998, Posse et al. 2000, SAVAdogo et al. 2007, vAN DER WAAL 2010). Fires have chemical and physical consequences, such as the mineralization of nutrients stimulating the growth of surviving species, the increase in soil compaction, soil temperature and a decrease in organic material in turn leading to lowered soil-water content (JEFFrey 1987, SNyman 1994). All these factors influence growing conditions for plants (MwAVU \& WITKOWSKI 2008) and may facilitate or hinder the development of individuals.

Summarizing these studies, one can assume that human land-use may have either positive or negative effects on the density of woody species seedlings and saplings due to the change of the physical and biological characteristics of the land-cover types caused by human impact. Therefore, we expect to observe a significant effect of human land use on the density of seedlings and saplings by affecting population structure of woody plants and altering abiotic and biotic habitat conditions (SWAINE 1996). We further assume that the strength of this effect is related to species' ecological preferences, which refer to the environmental conditions under which the species is most likely to occur. Within this study, we investigated patterns of population densities of a broad set of characteristic savanna species to obtain a better understanding of the influence of land use and related environmental factors on the juvenile stages of woody species. We aim to answer the following questions:

\section{- How are juvenile densities affected by land use?}

- Can we identify specific environmental conditions, soil conditions and vegetation structure, determining juvenile densities?

- Does the density of reproductive adults have an effect on juvenile densities? 


\section{Methods}

\subsection{Study site}

The study was carried out around Sampeto village $\left(11^{\circ} 40^{\prime}-12^{\circ} 23^{\prime} \mathrm{N}, 2^{\circ} 04^{\prime}-3^{\circ} 05^{\prime} \mathrm{E}\right)$ located in the northern part of Benin at the periphery of the W Transborder Park (Parc National $\mathrm{du} \mathrm{W}$ ), one of the largest protected areas in West Africa. Sampeto had 3725 inhabitants in 2013 (KNOEMA 2013), although this number has most likely increased since the last census. The area belongs to the North-Sudanian vegetation zone which is characterized by an average annual precipitation of 700-1000 $\mathrm{mm}$ and a 6 month lasting rainy season from May to October (BoNOU 2008).

All field data were collected in the surroundings of Sampeto (within maximal distance of $10 \mathrm{~km}$ ). The communal area of the village represents a typical example of a savanna landscape in West Africa with an alternating mosaic of croplands, fallows and non-arable land. The most common agricultural system is shifting cultivation where almost all land is used for agriculture excluding protected areas or areas illsuited due to their relief conditions or where we find crusted soils or soils containing a high amount of gravel (RUTHENBERG 1980, FAO 1983, OKigbo 1985, AlEXANDRE \& KAÏRÉ 2001). Because the location is at the periphery of a national park (W National Park), we were also able to consider sites which are less altered by human impact - the buffer zone of the national park - and represent semi-natural conditions.

Harvesting of NTFPs for firewood, medical purposes or livestock forage is common in the settlement area, thus fallow areas and non-arable areas are equally exposed to harvesting activities. In the buffer zone, these activities are limited by law, but still some illegal timber extraction occurs. An integral part of land use is extensive livestock breeding of both cattle and small ruminants such as goats and sheep. Mixed livestock in herds of different size are rotationally grazed during the day affecting all land-cover types through grazing and trampling. The buffer zone is mainly grazed by cattle, but generally less altered by livestock grazing activities compared with the communal area. Fires are irregularly set by the farmers once or twice during the dry season in order to support the re-growth of palatable forbs and grasses and for protection against intensive fires at the end of the dry season. In the buffer zone, early fires are set for management purposes at the beginning of the dry season and during a period of about six weeks (from 2004 to 2009, GRÉGOIRE \& SimONETTI 2010). The fire activity tends to increase and clearly indicates an increased overall anthropogenic pressure on the protected areas. The mean fire density was three fires per 1000 ha between 2004 and 2009, and is approximately the same in the buffer zone and the adjacent communal area (SUN 2010, unpubl. data).

Three land-cover types were studied. (1) Tree and shrub savanna on shallow skeletal soils without prior cultivation, but with frequent use of non-timber forest products (NTFPs) and as pasture. This habitat is dominated by the shrub species Detarium microcarpum whereas the herbaceous layer is sparsely developed (hereafter referred to as 'non-arable'). (2) Tree and shrub savanna on nutrient poor-to-medium, previously cultivated soils (at least $10 \mathrm{y}$ ago, with differ- ent crops), frequent use of NTFPs and as pasture. The canopy layer is composed of different woody plants; such as Piliostigma thonningii, Dichrostachys cinerea, Terminalia laxiflora and Flueggea virosa. The herb layer is characterized by Tephrosia pedicellata, Spermacoce ruelliae; Pennisetum polystachion, Desmodium velutinum and Chasmopodium caudatum (hereafter referred to as 'fallow'). (3) Semi-natural tree and shrub savanna on medium soils covered with tall grasses, such as Hyparrhenia involucrata and the perennial species Andropogon gayanus, where use of natural resources is limited due to regulation by law (hereafter referred to as 'buffer zone'). The latter is located in the buffer zone of the W National Park, while the first two landcover types can be found in the communal area. The studied land-cover types were comparable with respect to their adult vegetation composition (Appendix 1). Fallows and non-arable land are exposed to similar disturbance intensities (fire, grazing, harvesting) and are freely accessible. As a result of the stepwise land-use change, the landscape becomes fragmented and consists of patches of more or less native vegetation embedded into a matrix of different land-cover types, including non-arable sites and fallows (STOATE et al. 2001, GreEN et al. 2005, AbDUlLah \& NAKAgOSHi 2006).

\subsection{Vegetation data}

Within each of the three land-cover types we randomly chose plots for vegetation sampling. The minimal distance be-tween chosen plots was $100 \mathrm{~m}$. The woody layer was investigated in $900 \mathrm{~m}^{2}$ plots and the herb layer in $100 \mathrm{~m}^{2}$ plots. The herb layer plots were randomly located inside the corresponding woody layer plots. Percentage canopy coverage of all vascular plant species, separately for the tree, shrub and herb layer, was estimated visually on each plot (Nacoulma et al. 2011).

To examine the density of juveniles and adults adequately, squared plots of two sizes were established at each study site. Adult individuals were sampled on $1800 \mathrm{~m}^{2}$ plots, while juveniles were determined on four sub-plots (each with a size of $6.25 \mathrm{~m}^{2}$ ) nested in the $1800 \mathrm{~m}^{2}$ plots. In total, 39 of these $1800 \mathrm{~m}^{2}$ plots were investigated, 12 on nonarable sites, 17 on fallows, and 10 in the buffer zone. On each of the $6.25-\mathrm{m}^{2}$ subplots, numbers of juveniles were counted, comprising all young, immature individuals of the seedling and sapling stage smaller than $1 \mathrm{~m}$. We analyzed trees and shrubs separately. Trees were defined as single-stemmed individuals branched above breast height $(130 \mathrm{~cm})$. Shrubs were shorter than $10 \mathrm{~m}$ in height and either with several straight stems, visibly connected at ground level or one single trunk with attached branches below breast height (Powell 2005, Nzunda et al. 2007). Biometric data for adults with diameter at breast height ( $\mathrm{dbh}$ ) of more than $5 \mathrm{~cm}$ were collected, measuring $\mathrm{dbh}(\mathrm{cm})$ and height (m). For multi-stemmed individuals, all stems with dbh larger than $5 \mathrm{~cm}$ were measured. According to PRETZSCH (2002) we used the equation $\sqrt{ }\left(\sum \mathrm{d}_{\mathrm{i}}^{2}\right)$ to reduce multiple diameter of a multi-stemmed individual to a single composite measurement in order to be able to compare it with those of single-stemmed trees. 
To account for weather-related annual and seasonal variation, vegetation sampling was repeated five times. Three censuses were conducted at the end of the dry season (May/ June 2008, May/June 2009 and May/June 2010), and two were carried out at the end of the rainy season (September/October 2008 and September/October 2009). The plant species nomenclature followed the African Plants Database (http://www.ville-ge.ch/musinfo/bd/cjb/africa).

\subsection{Environmental data}

Environmental conditions were characterised by the vegetation structure and soil analysis. Structural characteristics of the land-cover types were described as cover and height of the tree and shrub layer (on plots of $1800 \mathrm{~m}^{2}$ ) and the herbaceous layer (on one subplot of $100 \mathrm{~m}^{2}$ ) in September/October 2007. Measurements were performed for the tree and shrub layer (woody plants $>5 \mathrm{~m}$ ) and the herbaceous layer (all plants up to $0.5 \mathrm{~m}$ in height).

On each of the $1800-\mathrm{m}^{2}$ plots, we took three randomly placed soil samples of the upper 0-20 cm layer in May 2009. These three samples were pooled and subsequently analysed for plant-available phosphorus, potassium, nitrogen, organic and inorganic carbon, cation exchange capacity (CEC, with ion concentrations of sodium, potassium, calcium, and magnesium), particle size distribution (PSD), and pH. Plantavailable phosphorus (phosphorus pentoxide, $\mathrm{P}_{2} \mathrm{O}_{5}$ ) and potassium (potassium oxide, $\mathrm{K}_{2} \mathrm{O}$ ) determination was carried out by calcium-acetate-lactate (CAL)-method (SCHÜLLER $1969,1973)$; $\mathrm{pH}$ was measured in aqueous solution against $0.1 \mathrm{M} \mathrm{KCl}$ (Meiwes et al. 1984) and $0.01 \mathrm{M} \mathrm{CaCl}_{2}$ solution (DIN 19 684, sheet 1 1977). We determined organic carbonate by the wet combustion method (Lichtenfelder (DIN 19 684, sheet 2 1977) and colorimetric detection using spectral photometer Cadas 100 (Lange). Nitrogen was determined quantitatively by the Kjeldahl-titrimetric method modified by Bremmer $(1960,1965)$. Cation exchange capacity and ion concentrations were determined in $\mathrm{BaCl}_{2}$ solution buffered with triethanolamine by the Mehlich-extraction method according to DIN 19 684, sheet 8 (1977). PSD for fine soil particles was determined with Köhn-pipette method (DIN 19 683, sheet 1 and 2 1973).

\subsection{Differences in environmental factors between land- cover types}

We calculated the mean of all environmental parameters per land-cover type and used Tukey's multiple comparison tests to search per environmental parameter for differences between land-cover types. Prior to statistical analysis, numerical variables were normalized by scaling them between zero and one. Such standardization is required to make the explanatory variables that were measured on different scales comparable. Furthermore, all environmental variables were checked for possible inter-correlations. Using a correlation threshold of $r^{2}>0.7$, we found that the amount of potassium and potassium oxide were highly correlated $\left(\mathrm{r}^{2}=\right.$ 0.785 ) and consequently removed potassium oxide from the further analyses (for Pearson correlation coefficients see Appendix 2).

\subsection{Influence of land use and environment on juvenile densities}

Juveniles were recorded individually, so we were able to distinguish between established individuals and new recruits. For our analysis, we only chose individuals that were present at the end of the dry season and at the end of the rainy season in 2009. In total, we considered 16 shrub and seven tree species (for density values see Appendix 3 ). To analyze if a population has good regeneration relative to the number of adult trees, we determined the mean of the density per hectare of adult individuals (trees: $\mathrm{dbh}>15 \mathrm{~cm}$. shrubs: $\mathrm{dbh}$ $>12 \mathrm{~cm}$ ) per species.

The statistical analyses addressed two different issues for each species: (1) to determine the influence of land use on juvenile densities, and (2) to determine which environmental conditions affect juvenile densities additional to the influence of land use.

To answer the first issue, we calculated a linear mixed-effect model (LME) with number of juveniles as response variable and land-cover type (factor) as explanatory variable was calculated. To correct for potential auto-correlation in time, we induced census as random factor. These LMEs were tested for differences between the land-cover types using Tukey's multiple comparison tests. Based on these tests, we merged land-cover types without significant differences, resulting in LMEs showing which land-cover types differ in seedling densities. Using these models, we assigned each tree and shrub species to a particular group. For example, two species that showed no statistical differences in juvenile densities between fallows and non-arable sites but differed from those in the buffer zone were grouped together even though the juvenile density of two species differed.

To address the environmental conditions which alter juvenile densities, in addition to the influence of land use, we searched for environmental parameters significantly related to each species group. Only environmental parameters differing between land-cover types were used. These preselected factors were taken as explanatory variables in generalized linear models (GLM using juvenile densities as dependent variable) using the quasi-Poisson model, as this model described the distribution of the residuals for count data, e.g. the juvenile densities, best. We performed a model simplification by omitting non-significant parameters until only significant parameters remained (CRAWLEY 2007).

All statistical analyses were done using the software package $\mathrm{R}$ (version 2.13.2) with the additional package vegan (version 2.0-5), "lme4" (version 0.999999-0) and "multcomp" (version 1.2-15).

\section{RESULTS}

\subsection{Differences in environmental factors between land- cover types}

We found 11 environmental parameters differing significantly between the land-cover types: height of herb layer, cover of tree/shrub and herb layer characterising the vegetation structure and eight soil parameters (Table 1). 
Table 1: Mean ( \pm SE) of 23 environmental parameters (soil parameters and vegetation structural data) per land-cover type. The samples were taken at 39 plots (12 on non-arable sites, 17 in fallows, 10 in the buffer zone), different letters (a, b and c) indicate significant differences $(\mathrm{P}<0.05$, highlighted with *). BS-value: percentage base saturation, S-value: Quantity of basic interchangeable Ions / Moyenne ( \pm SE) de 23 paramètres environnementaux (paramètres du sol et données structurelles de la végétation) par type de couvert végétal. Les échantillons ont été prélevés sur 39 parcelles (12 sur les sites non arables, 17 dans les jachères, 10 dans la zone tampon), différentes lettres ( $a, b$ et c) indiquent des différences significatives $(P<0,05$, accentué avec *). Valeur BS: pourcentage de saturation de base, valeur S: Quantité d'ions interchangeables de

\begin{tabular}{|c|c|c|c|}
\hline Environmental parameter & Non-arable $(n=12)$ & Fallows $(n=17)$ & Buffer zone $(n=10)$ \\
\hline Cover tree/shrub layer $(\%)^{*}$ & $29.8 \pm 4.71 \mathrm{a}$ & $19.7 \pm 1.29 \mathrm{ab}$ & $13.3 \pm 2.1 \mathrm{~b}$ \\
\hline Height herb layer $(\mathrm{cm})$ * & $50.2 \pm 12.46 \mathrm{a}$ & $42.8 \pm 6.32 \mathrm{a}$ & $184 \pm 5.42 \mathrm{~b}$ \\
\hline Cover herb layer $(\%)^{*}$ & $48.6 \pm 3.68 \mathrm{a}$ & $62.4 \pm 4.25 \mathrm{~b}$ & $71.9 \pm 2.61 \mathrm{~b}$ \\
\hline CECpot (cmolc/kg) * & $73.2 \pm 9.12 \mathrm{a}$ & $49.5 \pm 4.29 \mathrm{~b}$ & $38.1 \pm 5.14 b$ \\
\hline Medium silt (\%)* & $9.3 \pm 0.52 \mathrm{a}$ & $8.1 \pm 0.3 b$ & $8.6 \pm 0.47 \mathrm{ab}$ \\
\hline Clay $<2 \mu \mathrm{m}(\%) *$ & $21.1 \pm 1.34 \mathrm{a}$ & $18.6 \pm 1.04 \mathrm{a}$ & $13.4 \pm 0.6 \mathrm{~b}$ \\
\hline $\mathrm{K}_{2} \mathrm{O}(\mathrm{mg} / \mathbf{1 0 0 g}) *$ & $6.0 \pm 0.36 \mathrm{a}$ & $8.4 \pm 0.73 b$ & $7.8 \pm 0.77 \mathrm{ab}$ \\
\hline Coarse silt $(\%)^{*}$ & $32.4 \pm 1.35 \mathrm{ab}$ & $31.2 \pm 1.69 \mathrm{a}$ & $38.6 \pm 1.78 \mathrm{~b}$ \\
\hline $\mathrm{pH}^{*}$ & $4.8 \pm 3.07 \mathrm{a}$ & $5.4 \pm 2.83 \mathrm{~b}$ & $5.6 \pm 3.85 b$ \\
\hline $\mathrm{K}^{+}(\mathbf{m m o l c} / \mathbf{k g}) *$ & $0.8 \pm 0.05 \mathrm{a}$ & $1.1 \pm 0.11 \mathrm{ab}$ & $1.4 \pm 0.16 b$ \\
\hline BS-value* & $34 \pm 3.27 \mathrm{a}$ & $48.3 \pm 2.07 \mathrm{~b}$ & $54.9 \pm 2.78 \mathrm{~b}$ \\
\hline C/N-ratio & $20.1 \pm 2.08 \mathrm{a}$ & $22 \pm 2.18 \mathrm{a}$ & $20.4 \pm 2.51 \mathrm{a}$ \\
\hline $\mathrm{Ca}^{2+}(\mathrm{mmolc} / \mathrm{kg})$ & $25.9 \pm 1.17 \mathrm{a}$ & $35.4 \pm 3.89 \mathrm{a}$ & $34.6 \pm 5.21 \mathrm{a}$ \\
\hline Coarse sand (\%) & $7.9 \pm 1.54 \mathrm{a}$ & $8.6 \pm 1.89 \mathrm{a}$ & $6.4 \pm 2.22 \mathrm{a}$ \\
\hline C-organic (\%) & $1.8 \pm 0.16 \mathrm{a}$ & $1.7 \pm 0.18 \mathrm{a}$ & $1.5 \pm 0.16 \mathrm{a}$ \\
\hline Fine sand (\%) & $18.2 \pm 1.2 \mathrm{a}$ & $21.4 \pm 1.45 \mathrm{a}$ & $22.7 \pm 1.15 \mathrm{a}$ \\
\hline Fine silt (\%) & $4.1 \pm 0.22 \mathrm{a}$ & $3.8 \pm 0.23 \mathrm{a}$ & $3.9 \pm 0.15 \mathrm{a}$ \\
\hline Medium sand (\%) & $7.1 \pm 0.61 \mathrm{a}$ & $7.9 \pm 0.65 \mathrm{a}$ & $6.5 \pm 0.36 \mathrm{a}$ \\
\hline $\mathrm{Mg}^{2+}(\mathbf{m m o l c} / \mathbf{k g})$ & $7.7 \pm 0.78 \mathrm{a}$ & $10.5 \pm 0.85 \mathrm{a}$ & $10.7 \pm 1.2 \mathrm{a}$ \\
\hline $\mathrm{Na}^{+}(\mathrm{mmolc} / \mathrm{kg})$ & $0.4 \pm 0.07 \mathrm{a}$ & $0.3 \pm 0.03 \mathrm{a}$ & $0.3 \pm 0.04 \mathrm{a}$ \\
\hline N-total (\%) & $0.1 \pm 0.01 \mathrm{a}$ & $0.1 \pm 0 \mathrm{a}$ & $0.1 \pm 0.01 \mathrm{a}$ \\
\hline $\mathrm{P}_{2} \mathrm{O}_{5}(\mathrm{mg} / 100 \mathrm{~g})$ & $0.3 \pm 0.05 \mathrm{a}$ & $0.3 \pm 0.02 \mathrm{a}$ & $0.3 \pm 0.03 \mathrm{a}$ \\
\hline S-value & $34.8 \pm 1.36 \mathrm{a}$ & $47.4 \pm 4.6 \mathrm{a}$ & $47 \pm 6.31 \mathrm{a}$ \\
\hline
\end{tabular}

On non-arable sites, we detected the highest amount of acid exchangeable cations (CECpot), the lowest amount of exchangeable acid cations (BS-value), the lowest $\mathrm{pH}$ as well as the lowest percentage cover of the herb layer, which differed significantly from fallows and the buffer zone (Table 1). Site conditions on fallows were intermediate to those conditions on non-arable sites and the buffer zones, as we did not detect any environmental parameter that was significantly higher or lower on fallows compared to the other land-cover-types. The low percentage of clay in the subsurface and the height of the herb layer, were characteristic for the buffer zone and differed significantly from the communal area (non-arable sites and fallows).

\subsection{Influence of land use and environment on juvenile densities}

The 16 shrub and seven tree species were assigned to five groups (A-E). Each group comprises species responding similar to land use (Table 2). For groups A-D we detected several but different soil parameters as significantly related to juvenile densities, whereas no parameter was found for group E (Table 3).

The tree species Pterocarpus erinaceus was the only member of group A where juvenile densities differed between all land-cover types. Highest juvenile density of this species was found in the buffer zone whereas the highest number of adults was found on fallows. For species of group B ( $\mathrm{An}$ nona senegalensis, Crossopteryx febrifuga, Lannea acida and Terminalia avicennioides) no differences were found between non-arable land and fallows, but they differed from the buffer zone. All species had high juvenile densities in the communal area, especially on fallows: Only C. febrifu$g a$ showed more juveniles in the buffer zone compared to the communal area. For group A and B, the height of the herb layer was the only significant environmental parameter explaining differences in juvenile densities between all land-cover types and, and in the case of group B, between the communal area (non-arable and fallows) and the buffer zone. Group $\mathrm{C}$ was the largest group, comprising seven shrub and two tree species with similar densities on non-arable land and in the buffer zone, which differed from those on fallows. The vegetation structure (height of the herb layer and percentage cover of the tree/shrub layer), the amount of exchangeable acid cations (CECpot) and the percentage of the coarse-grained silt fraction were the parameters determining differences in the density of juveniles between fallows and those on non-arable sites and the buffer zone. Eight shrub and tree species, whose juvenile densities did not differ between fallows and the buffer zone but on non-arable 
Table 2: Juvenile densities, sampled on one subplot of $100 \mathrm{~m}^{2}$, of the 25 analyzed woody species. Densities are presented per land-cover type (non-arable land: $n=12$, fallow: $n=17$ and buffer zone: $n=10$ ). Similarity between land-cover types concerning the juvenile densities, calculated by a linear-mixed-effect model and a subsequent Tukey's multiple comparison test, is marked by (\&), dissimilarity by $(\neq)$. Growth form: S: shrub, T: tree. / Densités juvéniles, échantillonnées sur une sous-parcelle de $100 \mathrm{~m}^{2}$, des 25 espèces ligneuses analysées. Les densités sont présentées par type de couvert végétal (terres non arables: $n=12$, jachère: $n=17$ et zone tampon: $n=10$ ). La similitude entre les types de couverture concernant les densités juvéniles, calculée par un modèle à effet mixte linéaire et un test de comparaison multiple de Tukey subséquent, est indiquée par $(\&)$, dissimilarité par $(\neq)$. Forme de croissance:

S: arbuste, T: arbre.

\begin{tabular}{|c|c|c|c|c|}
\hline \multirow[t]{2}{*}{ Species } & \multirow[t]{2}{*}{ Family } & \multicolumn{3}{|c|}{ Land-cover type } \\
\hline & & Non-arable & Fallow & Buffer zone \\
\hline \multicolumn{5}{|c|}{ Group A: non-arable $\neq$ fallows $\neq$ buffer zone } \\
\hline Pterocarpus erinaceus $(\mathrm{T})$ & Fabaceae & $23 \pm 3.1$ & $10 \pm 1.7$ & $38 \pm 5.4$ \\
\hline \multicolumn{5}{|c|}{ Group B: non-arable \& fallows $\neq$ buffer zone } \\
\hline Annona senegalensis ( $\mathrm{S})$ & Annonaceae & $43 \pm 6.4$ & $62 \pm 5.8$ & $0 \pm 0.5$ \\
\hline Crossopteryx febrifuga $(\mathrm{S})$ & Rubiaceae & $15 \pm 3.4$ & $10 \pm 1.7$ & $23 \pm 5.0$ \\
\hline Lannea acida $(\mathrm{T})$ & Anacardiaceae & $26 \pm 4.4$ & $36 \pm 4.1$ & $2 \pm 1.1$ \\
\hline Terminalia avicennioides $(\mathrm{T})$ & Combretaceae & $36 \pm 6.1$ & $49 \pm 5.4$ & $10 \pm 3.2$ \\
\hline \multicolumn{5}{|c|}{ Group C: non-arable \& buffer zone $\neq$ fallows } \\
\hline Acacia hockii (S) & Mimosaceae & $0 \pm 0.0$ & $13 \pm 3.2$ & $2 \pm 1.0$ \\
\hline Anogeissus leiocarpa $(\mathrm{T})$ & Combretaceae & $27 \pm 7.0$ & $79 \pm 14.7$ & $12 \pm 34$ \\
\hline Combretum collinum $(\mathrm{S})$ & Combretaceae & $45 \pm 5.0$ & $133 \pm 15.7$ & $31 \pm 7.8$ \\
\hline Dichrostachys cinerea $(\mathrm{S})$ & Mimosaceae & $126 \pm 25.8$ & $223 \pm 29.6$ & $14 \pm 4.6$ \\
\hline Diospyros mespiliformis $(\mathrm{S})$ & Ebenaceae & $1 \pm 0.7$ & $54 \pm 11.2$ & $2 \pm 1.0$ \\
\hline Feretia apodanthera $(\mathrm{S})$ & Rubiaceae & $7 \pm 1.7$ & $68 \pm 11.8$ & $2 \pm 1.0$ \\
\hline Gardenia ternifolia $(\mathrm{S})$ & Rubiaceae & $22 \pm 5.4$ & $13 \pm 2.0$ & $14 \pm 3.7$ \\
\hline Piliostigma thonningii (S) & Caesalpiniaceae & $13 \pm 2.2$ & $43 \pm 4.3$ & $4 \pm 1.3$ \\
\hline Strychnos spinosa $(\mathrm{S})$ & Strychnaceae & $35 \pm 5.8$ & $26 \pm 3.4$ & $57 \pm 7.6$ \\
\hline Vitellaria paradoxa $(\mathrm{T})$ & Sapotaceae & $40 \pm 13.5$ & $85 \pm 15.8$ & $14 \pm 2.9$ \\
\hline \multicolumn{5}{|c|}{ Group D: fallows \& buffer zone $\neq$ non-arable } \\
\hline Combretum glutinosum $(\mathrm{S})$ & Combretaceae & $23 \pm 4.0$ & $4 \pm 1.1$ & $4 \pm 1.3$ \\
\hline Combretum nigricans $(\mathrm{S})$ & Combretaceae & $93 \pm 16.1$ & $34 \pm 5.5$ & $10 \pm 2.3$ \\
\hline Detarium microcarpum $(\mathrm{S})$ & Caesalpiniaceae & $461 \pm 53.7$ & $45 \pm 6.7$ & $0 \pm 0.0$ \\
\hline Isoberlinia doka $(\mathrm{T})$ & Caesalpiniaceae & $12 \pm 2.7$ & $43 \pm 4.9$ & $35 \pm 6.3$ \\
\hline Philenoptera laxiflora $(\mathrm{T})$ & Fabaceae & $1 \pm 0.6$ & $19 \pm 4.8$ & $30 \pm 5.2$ \\
\hline Pteleopsis suberosa $(\mathrm{T})$ & Combretaceae & $222 \pm 41.8$ & $71 \pm 9.8$ & $2 \pm 1.0$ \\
\hline Stereospermum kunthianum $(\mathrm{T})$ & Bignoniaceae & $95 \pm 9.4$ & $44 \pm 5.3$ & $30 \pm 4.9$ \\
\hline \multicolumn{5}{|c|}{ Group E: non-arable \& fallows \& buffer zone } \\
\hline Bombax costatum $(\mathrm{T})$ & Bombacaceae & $7 \pm 1.6$ & $9 \pm 1.8$ & $8 \pm 1.8$ \\
\hline Combretum molle (S) & Combretaceae & $68 \pm 9.6$ & $65 \pm 6.7$ & $69 \pm 13.4$ \\
\hline Gardenia aqualla $(\mathrm{S})$ & Rubiaceae & $4 \pm 1.8$ & $9 \pm 3.0$ & $8 \pm 2.3$ \\
\hline
\end{tabular}

sites, were assigned to group D. Some species (Combretum glutinosum, Detarium microcarpum, Pteleopsis suberosa and Stereospermum kunthianum) had the highest juvenile densities on those non-arable sites where we also found a high number of adult individuals of this species (Table 4). In the case of Combretum nigricans, we found the highest recruitment rates on non-arable site but less adult individuals compared to fallows. Differences in the percentage cover of the herb layer, $\mathrm{pH}, \mathrm{CECpot}$ and the percentage of clay in the top-soil were the most important soil parameters significantly impacting on juvenile densities of species affiliated to group D. Species of group E (Bombax costatum, Combretum molle, Gardenia aqualla) showed no influence of land use on juvenile abundances (Tables 2, 3). For B. costatum, juvenile densities were low in all land cover types similar as the number of adults. The shrub species C. molle showed high recruitment rates in all land cover types which corresponded well to similarly high number of adults (Table 4).

\section{Discussion}

\subsection{Differences in environmental facts between land- cover types}

The detected differences between different land-cover types due to chemical and physical soil properties as well as characteristics of the vegetation structure were in line with observations by HAHN (1996) that physical soil properties determined the occurrence of vegetation types in West African savannas. However, as also found by OrTHMANN (2005), we 
Table 3: Influence of environmental factors on juvenile densities by species affiliation groups A-E. The GLMs (quasi-Poisson model) were fitted using juvenile densities as dependent variable, and environmental variables (numerical) as explanatory variables. / Influence des facteurs environnementaux sur les densités juvéniles selon les groupes d'affiliation des espèces A-E. Les GLM (quasiPoisson model) ont été ajustés en utilisant la densité juvénile comme variable dépendante et les variables environnementales (numériques) comme variables explicatives.

\begin{tabular}{|c|c|c|c|c|}
\hline & Estimate & SE & t value & $\operatorname{Pr}(>|t|)$ \\
\hline \multicolumn{5}{|c|}{ group A: non-arable $\neq$ fallows $\neq$ buffer zone } \\
\hline Intercept & 5.63 & 0.21 & 26.6 & $<0.001^{* * *}$ \\
\hline Height herb layer (cm) & 0.55 & 0.17 & 3.2 & $0.003^{* *}$ \\
\hline \multicolumn{5}{|c|}{ group B: non-arable \& fallows $\neq$ buffer zone } \\
\hline Intercept & 6.02 & 0.14 & 42.9 & $<0.001 * * *$ \\
\hline Height herb layer cm) & -0.48 & 0.17 & -2.9 & $0.005^{* *}$ \\
\hline \multicolumn{5}{|c|}{ group C: non-arable \& buffer zone $\neq$ fallows } \\
\hline Intercept & 63.75 & 0.15 & 45.9 & $<0.001 * * *$ \\
\hline Height herb layer $(\mathrm{cm})$ & -0.64 & 0.17 & -3.7 & $<0.001 * * *$ \\
\hline Cover tree/shrub layer (\%) & 0.29 & 0.13 & 2.2 & $0.026^{*}$ \\
\hline CECpot (cmolc/kg) & -0.45 & 0.17 & -2.7 & $0.007 * *$ \\
\hline Medium silt (\%) & -0.29 & 0.13 & -2.3 & $0.023 *$ \\
\hline \multicolumn{5}{|c|}{ group D: non-arable $\neq$ fallows \& buffer zone } \\
\hline (Intercept) & 6.34 & 0.16 & 39.4 & $<0.001 * * *$ \\
\hline Cover herb layer (\%) & -0.34 & 0.17 & -2.0 & $0.043 *$ \\
\hline pH & -0.62 & 0.23 & -2.7 & $0.007 * *$ \\
\hline CECpot (cmolc/kg) & 0.61 & 0.14 & 4.3 & $<0.001 * * *$ \\
\hline Clay $<2 \mu \mathrm{m}(\%)$ & -0.49 & 0.14 & -3.4 & $<0.001 * * *$ \\
\hline \multicolumn{5}{|c|}{ group E: non-arable \& fallows \& buffer zone } \\
\hline (Intercept) & 6.10 & 0.20 & 30.4 & $<0.001 * * *$ \\
\hline
\end{tabular}

additionally detected soil acidity and alkalinity indicated by $\mathrm{pH}$ and percentage base saturation (BS-Value) as important factors differing between land-cover types; in our case the values were increased in the communal area (non-arable sites and fallows) compared to the buffer zone.

\subsection{Influence of land use and environment on juvenile densities}

In general, in grass-dominated savanna ecosystems, juveniles compete during the establishment and initial growth mainly with stand-forming tall grasses. Such grasses as Andropogon gayanus and Hyparrhenia involucrata can be frequently found in high abundances in the buffer zone. However, we detected a high number of juveniles of Pterocarpus erinaceus in the buffer zone; thus, we suppose that other factors besides the competition between young woody plants and grasses are responsible for the contrasting performance pattern. This species is one of the five most important fodder tree species in the study area (L. Houessou, pers. comm.) and is pruned to provide additional forage for the livestock during the dry season. Higher densities of large reproductive trees were found on fallows compared to the buffer zone as many mature trees are maintained when land is cleared for agriculture due to the immediate value of the foliage for the cattle. This may influence the relative abundance of regeneration detectable on a site (MiLTON 1995). Aside from the fact that cutting of large stems and pollarding in the buffer zone is prohibited and can have a significant impact on reproduction and on population viability over the long term (Dhillion \& Gustad 2004, GaOue
\& Ticktin 2008, Hall \& Bawa 1993, Peters 1990), high juvenile densities may be due to a reduced grazing intensity in the buffer zone as young leaves of this species are preferably consumed by livestock (BAYER 1990, Duvall 2008, GLELE KAKAÏ et al. 2009).

The lower juvenile density of Crossopteryx febrifuga in the communal area compared to the buffer zone may be linked to the high grazing pressure in the communal area that may reduce the number of young plants. The species re-sprouts early after the dry season and is preferably browsed by cattle as our grazing observations have shown. These observations are supported by our results of a previous study where we detected many reproductive trees in the communal area, especially on non-arable sites (JURISCH et al. 2012). For the buffer zone our results imply that the high amount of silt relates to an increased water-holding capacity compared to non-arable sites and fallows. Thus, coupled with a high percentage base saturation, the soils in the buffer zone provide ideal growing conditions for plants. On sites where nutrient availability and water supply are high, grasses, in particular, can quickly form an almost continuous vegetation cover and may repress juvenile woody plants by competing for light, water and nutrients during their establishment and initial growth phase (HARPER 1977, JURENA \& ARCHER 2003, Riginos 2009, VANDENBERGHe et al. 2006). This corresponds to the findings from Mwavu et al. (2009) who detected competition by the ground vegetation as the most important factor reducing the survivorship of slower-growing, young woody plants. As detected in this study, the result is a reduced seedling density. Additionally, the tall grasses 
Table 4: Mean ( \pm S.E.) of the density (ha) of adult individuals per species. For shrubs, adult individuals have a diameter in breast height $(\mathrm{dbh})>12 \mathrm{~cm}$ and trees: $\mathbf{d b h}>15 \mathrm{~cm}$. For group details see Table 1. / Moyenne $( \pm \mathrm{S}$.E.) de la densité (ha) d'individus adultes par espèce. Pour les arbustes, les individus adultes ont un diamètre en hauteur de poitrine (dbh) $>12 \mathrm{~cm}$ et $\mathrm{arbres}$ : $\mathrm{dbh}>15 \mathrm{~cm}$. Pour les détails du groupe, voir le tableau 1.

\begin{tabular}{|c|c|c|c|c|}
\hline \multirow[t]{2}{*}{ Life form } & \multirow[t]{2}{*}{ Species } & \multicolumn{3}{|l|}{ Adults } \\
\hline & & Non-arable & Fallows & Buffer zone \\
\hline \multicolumn{5}{|c|}{ Group A: non-arable $\neq$ fallows $\neq \neq$ buffer zone } \\
\hline tree & Pterocarpus erinaceus Poir. & $0.2 \pm 0.1$ & $0.5 \pm 0.2$ & $0.2 \pm 0.1$ \\
\hline \multicolumn{5}{|c|}{ group B: non-arable $\&$ fallows $\neq$ buffer zone } \\
\hline shrub & Annona senegalensis Pers. & $1.2 \pm 0.4$ & $0.5 \pm 0.3$ & $0.0 \pm 0.0$ \\
\hline shrub & Crossopteryx febrifuga (Afzel. ex G.Don) Benth. & $6.6 \pm 1.4$ & $0.9 \pm 0.3$ & $5.0 \pm 1.0$ \\
\hline tree & Lannea acida A.Rich. & $1.2 \pm 0.3$ & $0.9 \pm 0.2$ & $2.1 \pm 0.5$ \\
\hline tree & Terminalia avicennioides Guill. \& Perr. & $1.2 \pm 0.5$ & $0.4 \pm 0.1$ & $0.3 \pm 0.2$ \\
\hline \multicolumn{5}{|c|}{ Group C: non-arable \& buffer zone $\neq$ fallows } \\
\hline shrub & Acacia hockii De Wild. & $0.0 \pm 0.0$ & $0.1 \pm 0.1$ & $0.0 \pm 0.0$ \\
\hline tree & Anogeissus leiocarpa (DC.) Guill. \& Perr. & $0.1 \pm 0.1$ & $0.8 \pm 0.3$ & $0.8 \pm 0.3$ \\
\hline shrub & Combretum collinum Fresen. & $0.8 \pm 0.5$ & $1.4 \pm 0.4$ & $0.4 \pm 0.3$ \\
\hline shrub & Dichrostachys cinerea (L.) Wight \& Arn. & $0.0 \pm 0.0$ & $0.1 \pm 0.1$ & $0.0 \pm 0.0$ \\
\hline shrub & Diospyros mespiliformis Hochst. ex A.DC. & $0.2 \pm 0.2$ & $0.4 \pm 0.3$ & $0.0 \pm 0.0$ \\
\hline shrub & Feretia apodanthera Delile & $0.3 \pm 0.2$ & $0.3 \pm 0.2$ & $0.4 \pm 0.3$ \\
\hline shrub & Piliostigma thonningii (Schumach.) Milne-Redh. & $0.3 \pm 0.2$ & $3.0 \pm 0.8$ & $0.4 \pm 0.3$ \\
\hline shrub & Strychnos spinosa Lam. & $0.6 \pm 0.4$ & $0.1 \pm 0.1$ & $0.4 \pm 0.3$ \\
\hline tree & Vitellaria paradoxa C.F.Gaertn. & $2.5 \pm 0.5$ & $2.5 \pm 0.5$ & $4.0 \pm 1.1$ \\
\hline \multicolumn{5}{|c|}{ Group D: non-arable $\neq$ fallows \& buffer zone } \\
\hline shrub & Combretum glutinosum Perr. ex DC. & $2.9 \pm 0.7$ & $0.8 \pm 0.3$ & $0.7 \pm 0.4$ \\
\hline shrub & Combretum nigricans Lepr. ex Guill. \& Perr. & $1.2 \pm 0.6$ & $2.0 \pm 0.8$ & $0.0 \pm 0.0$ \\
\hline shrub & Detarium microcarpum Guill. \& Perr. & $14.2 \pm 4.3$ & $0.7 \pm 0.3$ & $1.1 \pm 0.6$ \\
\hline shrub & Gardenia ternifolia Schumach. \& Thonn. & $0.2 \pm 0.2$ & $0.2 \pm 0.2$ & $0.0 \pm 0.0$ \\
\hline tree & Isoberlinia doka Craib \& Stapf & $1.5 \pm 0.4$ & $2.3 \pm 0.5$ & $4.3 \pm 1.1$ \\
\hline tree & Philenoptera laxiflora (Guill. \& Perr.) Roberty & $0.0 \pm 0.0$ & $0.0 \pm 0.0$ & $0.6 \pm 0.3$ \\
\hline shrub & Pteleopsis suberosa Engl. \& Diels & $1.4 \pm 0.6$ & $0.1 \pm 0.1$ & $0.0 \pm 0.0$ \\
\hline tree & Stereospermum kunthianum Cham. & $0.1 \pm 0.1$ & $0.0 \pm 0.0$ & $0.0 \pm 0.0$ \\
\hline \multicolumn{5}{|c|}{ Group E: non-arable \& fallows \& buffer zone } \\
\hline tree & Bombax costatum Pellegr. \& Vuill. & $0.0 \pm 0.0$ & $0.1 \pm 0.1$ & $0.1 \pm 0.1$ \\
\hline shrub & Combretum molle R.Br. ex G.Don & $2.0 \pm 0.5$ & $3.2 \pm 1.0$ & $2.5 \pm 0.6$ \\
\hline shrub & Gardenia aqualla Stapf \& Hutch. & $0.0 \pm 0.0$ & $0.0 \pm 0.0$ & $0.7 \pm 0.6$ \\
\hline
\end{tabular}

increase the fuel load and therefore, the potential for highintensity fires causing a decrease in juvenile densities due to fire-induced mortality (BATIONO et al. 2001, LuOGA et al. 2004, ZIDA 2007). However, burning may stimulate the growth of surviving species and the colonization of species because of the release of plant nutrients and through a range of indirect effects, e.g. decreased shade, higher soil temperatures and reduced competition affecting the growing performance of young plants ('ash-bed' effect, HARPER 1977, JEFFREY 1987, RiginOS 2009, VANDENBERGHE et al. 2006).

For species affiliated to group $\mathrm{C}$, beneficial effects through human-induced disturbances positively affect juvenile densities, as their juvenile densities are highest on fallows (but compare Gardenia ternifolia and Strychnos spinosa). These species are well adapted to the alternating cycles of cultivation and fallows like the shrub Combretum collinum (NACOUlma et al. 2011), and Piliostigma thonningii which is known as invasive species on fallows regenerating from the remaining rootstock left after the field clearing (ARBONNIER 2002, Bellefontaine 2005, Nikiema 2005). The competitive strength of these species is expressed by their healthy population structure, showing well-shaped size-class distributions with high numbers of juveniles and a gradual decline with increasing stem diameter (JURISCH et al. 2012). In this study, we also detected a high juvenile density and a large number of adult trees for $P$. thonningii. Human activities can have an indirect positive effect on seedlings and saplings by providing diverse, small-scale habitats that vary in time, such as bare soils on fallows, or by reducing vegetation cover. We found that percentage cover of the tree and shrub layer and the height of the herb layer positively affect juvenile densities on fallows. Such opening of the canopy is beneficial for the germination of seeds; in particular pioneer species like Anogeissus leiocarpa, whose seeds primarily germinate on bare soils, are favoured on fallows compared to sites with a dense vegetation cover (BoGNOUNOU et al. 2010, SACANDE \& SANOGo 2007). We also suppose 
that the facilitation of some species by traditionally managed agroforestry systems can affect woody plant populations by altering the relationship between juveniles and adult trees (JuRISCH et al. 2012, PARE et al. 2009). Vitellaria paradoxa, the shea tree, has a high socioeconomic importance and in particular, individuals with a high fruit yield are spared when woodland is cleared for agriculture (LOVETT \& HAQ 2000). Once the land becomes inadequate for crop production, it is abandoned and a few trees producing high numbers of off-springs are left. This may explain the high number of juveniles for $V$. paradoxa in fallows and a low number of adults compared to the buffer zone, where we found significantly less juveniles.

For species assigned to group D (non-arable sites differed from fallows and the buffer zone), high juvenile densities of some species (Detarium microcarpum, Combretum glutinosum, C. nigricans, Pteleopsis suberosa and Stereospermum kunthianum) might be related to species' ecological preferences or tolerance to specific soil conditions, such as increased soil acidity. The soils of non-arable sites were more acidic than those on fallows and in the buffer zone (high CECpot and low $\mathrm{pH}$ ); nevertheless, the soils were only slightly acidic which promotes nutrient availability and plant growth. However, for two species, Isoberlinia doka and Philenoptera laxiflora, we detected the lowest juvenile density on non-arable sites compared to fallows and the buffer zone. Although ARBONNIER (2002) indicated habitat preferences for I. doka to loamy, well-drained soils, we suppose that rather human-induced changes in the population structure affect juvenile densities of this species (JURISCH et al. 2012). Low numbers of juveniles may be due to a low density of mature individuals on non-arable sites, producing less offspring, or in the case of P. laxiflora, leaves are preferably browsed or used as fodder for goats (ARBONNIER 2002, L. Houessou, pers. comm.), which may limit the number of juveniles and reduce the population viability as well (Dhillion \& Gustad 2004, GaOue \& Ticktin 2008, Hall \& Bawa 1993). For I. doka, some studies showed that the density of seedlings and saplings was more abundant below mature trees as the main dispersal mode of the species is dropping the seeds from pods under the mother tree and suckering that encourage aggregated distribution (BATIONO et al. 2005, Dourma et al. 2006). Habitat loss and accelerated mortality of adults may have a great impact on juvenile densities of such species where the larger mother tree shelters the smaller, fire and drought sensitive seedlings. The species $P$. laxiflora mainly reproduces by seeds, thus, low numbers of juveniles may be due to the lack of reproductive individuals. In comparison, for D. microcarpum, C. nigricans, $P$. suberosa and $S$. kunthianum, the number of mature individuals was highest on non-arable sites compared to fallows and the buffer zone. The ability of vegetative reproduction can also be important for explaining differences between adult and juveniles densities, such as in the case of S. kunthianum. For this species, a low number of adults or even the lack of adults, such as in fallows and in the buffer zone, does not necessarily have implications for the number of observed juveniles. For S. kunthianum it is known, for example, that once established, juveniles develop extensive and widespread root systems under the soil surface, enabling them to set up offspring through vegetative repro- duction, building a net of connected juveniles (HoFFMAN et al. 2004; OuEDraOgo 2006; GrossnicKLE 2005; Wigley et al. 2009).

Juvenile densities of Combretum molle were high in all land-cover types what is consistent with findings of a former study, where we detected a similar pattern for subadult and adult individuals of $C$. molle, in relation to land use (JuRISCH et al. 2012). This species is not site-specific and shows wide ecological amplitudes (ARBONNIER 2002, OrwA et al. 2009). The species-specific characteristics, to repro-duce vegetatively and to re-sprout after damaging, enhance its competitive strength and allow its persistence in many habitats (Bond \& Midgley 2001, Devineau \& Fournier 2005, DrobNIK et al. 2011, LAVOREL et al. 1997). However, Gardenia aqualla preferably grows in shady depressions or on alluvial terraces and has a scattered distribution by nature (ARBONNIER 2002) which might result in this low number of juveniles in all land-cover types. Gardenia aqualla is characteristic for sites with low vegetation cover (SchmidT \& ZIZKA 2014). The affiliation of B. costatum to this group might indicate an overall harvesting pressure across the species in all land-cover types; the wood of this tree species is usable as lumber and its fibers are mainly used for stuffing, especially for mattresses and pillows (ArbonNier 2002, Oyen 2011). The flowers are the main ingredient for a sauce and were often collected through cutting of the entire branch. As mentioned before, the removal of large reproductive trees and plant parts can reduce the availability of seeds and might reduce the overall density of juveniles in an area if the impact is not compensated by their life histories as is the case for B. costatum (GAOUE \& Ticktin 2008, Schumann et al. 2011, Ticktin 2004). Furthermore, its leaves are highly digestible and eaten by livestock, further reducing the number of young individuals.

\section{Conclusion}

Land use was shown to significantly affect juvenile densities of almost all studied woody species, as demonstrated by a grouping of species according to their observed densities. Almost all species (20 out of 25 species) showed higher juvenile densities in the communal area compared to the buffer zone. For those species, we also expect a positive development of the population in the long-run as many woody species showed high survival and growth rates in the communal area (survival probability $>1 * 10^{-6}$, JURISCH et al. 2013). We have shown that many species regenerate well despite low numbers of adult individuals. Thus, it seems that dispersal limitation is not the major factor controlling juvenile densities (see also PARE et al. 2009).

We determined that the soil acidity and physical properties of the soil sub-surface horizon and vegetation structure are important factors differing between the land-cover types non-arable, fallows and the buffer zone. Although we detected significant differences in soil properties, their direct effects on juvenile densities are less pronounced than their indirect effects by altering the availability of resources (water and nutrients) for plants. Particularly in the buffer zone, the effect of below- and above-ground competition for space, light, water and nutrients may rather limit esta- 
blishment and growth of seedlings and saplings, indicating a strong impact of human activities on plant populations by altering the relative ratio between grasses and woody plants (Bond 2008, Sankaran et al. 2008, Scholes \& ArCHER 1997). We showed that physical soil properties affect growing conditions for juveniles on non-arable sites and on fallows; especially through its effect on the amount of water that can be held and on the distribution of water within the soil. A good water-holding capacity of the soil might extend the growing season for a longer time by preserving soil water into the dry season or between rainfalls (MCNAUGHTON et al. 1983) and thus enhance the establishment of juveniles. For plants growing on non-arable sites, drought resistance as well as early development of an effective root system to gain access to water may be an important feature enhancing the individual's ability to low rainfall.

Due to the ongoing land use changes causing habitat loss, the shortening of fallow periods, and over-grazing, diverse sites for juveniles are becoming diminished. This development becomes more pronounced as the current adult populations are already under high human pressure (e.g. harvesting of non-timber forest products), causing removal and impairment of the vitality of reproductive individuals. This can reduce the availability of seeds and may thereby lead to a lack of regeneration (Makana \& ThOMas 2006, McLaren et al. 2005, Plumptre 1995).

Both processes, loss of established individuals as a potential seed source and lack of regeneration due to high juvenile mortality by environmental factors, may result in a total loss of recruitment in an area. More studies on populations in their natural habitat, specifically in relation to land use and environmental conditions, are required to develop speciesspecific management strategies for allowing a high amount of natural regeneration to occur. Those studies should also investigate ecological characteristics such as dispersal ability, as the exchange of individuals between suitable habitats becomes important in fragmented landscapes and in areas where domestic animals and humans play a significant role in seed dispersal.

\section{ACKNOWLEDGMents}

This study was funded by SUN (FP7 INCO-dev 031685). The authors thank also the 'LOEWE Program (Landes-Offensive zur Entwicklung Wissenschaftlich-ökonomischer Exzellenz) of the State of Hesse for financial support of the Biodiversity and Climate Research Centre (BiK-F). We thank Prof. Brice Sinsin and Sylvain Gbohayida (Laboratory of Applied Ecology, University of Abomey-Calavi, Benin) for logistics and support during fieldwork. We acknowledge Bio Sibou, who assisted during fieldwork. We thank the people of Sampeto for their cooperation during data collection and extend a special thanks to Laurent Houessou for the time we shared during the field work.

\section{REFERENCES}

Abrahamson, WG (1980): Demography and vegetative reproduction. In Solbrig, OT (ed) Demography and Evolution in Plant Populations. University of California Press, Berkeley. 89-106.

ACACio V, Holmgren M, Jansen PA \& Schrotter O (2007): Multiple recruitment limitation causes arrested succession in Mediterranean cork oak systems. Ecosystems 10: 1220-1230.
ArbonNiER M (2002): Arbres, arbustes et lianes des zones sèches d'Afrique de l'Ouest (2nd ed.). CIRAD/MNHN, Montpellier/Paris. 574 p.

BAKKeR JP \& DE VRIES Y (1992): Germination and early establishment of lower salt-marsh species in grazed and mown salt marsh. J Veg Sci 3: 247-252.

Bationo BA, Ouedraogo SJ \& Guinko S (2001): Stratégies de régénération naturelle de Detarium microcarpum Guill. et Perr. dans la forêt classée de Nazinon (Burkina Faso). Fruits 56: 271-285.

BAYER W (1990): Use of native browse by Fulani cattle in Central Nigeria. Agrofor Syst 12: 217-228.

Bellefontaine R (2005): Pour de nombreux ligneux, la reproduction sexuée n'est pas la seule voie: analyse de 875 cas - Texte introductif, tableau et bibliographie. Sécheresse 1E: $38 \mathrm{p}$.

Bognounou F, Tigabu M, Savadogo P, Thiombiano A, Boussim IJ, ODEN PC \& Guinko S (2010): Regeneration of five Combretaceae species along a latitudinal gradient in Sahelo-Sudanian zone of Burkina Faso. Ann For Sci 67: 306-315.

Bond WJ (2008): What limits trees in C-4 grasslands and savannas? Annu Rev Ecol Evol Syst 39: 641-659.

Bond WJ \& Midgley JJ (2001): Ecology of sprouting in woody plants: the persistence niche. Trends Ecol Evol 16: 45-51.

Bonou A (2008): Estimation de la valeur économique des Produits Forestier Non Ligneux (PFNL) d'origine végétale dans le village Sampéto (commune de Banikoara). $\mathrm{PhD}$ thesis, University of Abomey-Calavi.

BRADY NC \& WEIL RR (1999): The nature and properties of soils. (12th ed.). Prentice-Hall, Upper Saddle River. 881 p.

BREMAN H \& KeSSLER JJ (1995): Woody plants in agro-ecosystems of semi-arid regions: with an emphasis on the Sahelian countries. (1st ed.). Springer, Berlin. 340 pp.

BREMNER JM (1960): Determination of nitrogen in soil by the Kjeldahl method. J. Agric. Sci. 55: 11-33.

Bremner JM (1965): Total nitrogen. Pp. In Black CA (ed) Methods of soil analysis. Part 2. Chemical and microbiological properties. (1st ed., 1149-1178. American Society of Agronomy, Madison. $1572 \mathrm{p}$.

BUSH JK \& VANAUKEN OW (1995): Woody plant-growth related to planting time and clipping of a C-4 Grass. Ecol 76: 1603-1609.

CARDON D \& JANSEN PCM (2005): Philenoptera laxiflora (Guill. \& Perr.) Roberty In JANSEN PCM \& CARDON D (eds) PROTA 3: Dyes and tannins/Colorants et tanins. (CD-Rom). PROTA, Wageningen, Netherlands.

Crawley MJ (2007): The R book (1st ed.). John Wiley \& Sons, London. 942 p.

Descroix L, Mahe G, Lebel T, Favreau G, Galle S, Gautier E, Olivry JC, Albergel J, Amogu O, Cappelaere B, Dessouassi R, Diedhiou A, Le Breton E, Mamadou I \& Sighomnou D (2009): Spatio-Temporal Variability Of Hydrological Regimes Around The Boundaries Between Sahelian And Sudanian Areas Of West Africa: A Synthesis. J Hydrol 375: 90-102.

DeVINEAU JL \& Fournier A (2005): To what extent can simple plant biological traits account for the response of the herbaceous layer to environmental changes in fallow-savan- 
na vegetation (West Burkina Faso, West Africa)? Flora 200: 361-375.

DHILLION SS \& GUSTAD G (2004): Local management practices influence the viability of the baobab (Adansonia digitata Linn.) in different land use types, Cinzana, Mali. Agric Ecosyst Environ 101: 85-103.

DIN - DeUTSChES INSTITUT FÜR NORMUNG 19683-1 (1973): Bodenuntersuchungsverfahren im landwirtschaftlichen Wasserbau - Physikalische Laboruntersuchungen Bestimmung der Korngrößenzusammensetzung durch Siebung. Deutsches Institut für Normung e.V., Beuth, Berlin.

DIN - Deutsches Institut Für NoRmung 19683-2 (1973): Bodenuntersuchungsverfahren im landwirtschaftlichen Wasserbau - Physikalische Laboruntersuchungen - Bestimmung der Korngrößenzusammensetzung nach Vorbehandlung mit Natriumpyrophosphat. Deutsches Institut für Normung e.V., Beuth Verlag, Berlin.

DIN - Deutsches Institut FÜr NoRmung 19684-1 (1977): Bodenuntersuchungsverfahren im landwirtschaftlichen Wasserbau - Chemische Laboruntersuchungen - Bestimmung des pH-Wertes des Bodens und Ermittlung des Kalkbedarfs. Deutsches Institut für Normung e.V., Beuth, Berlin.

DIN - DeUtsChes Institut FÜR NORMUNG 19684-2 (1977): Bodenuntersuchungsverfahren im landwirtschaftlichen Wasserbau - Chemische Laboruntersuchungen - Bestimmung des Humusgehaltes im Boden. Deutsches Institut für Normung e.V., Beuth, Berlin.

DIN - Deutsches Institut FÜR NORMUng 19684-8 (1977): Bodenuntersuchungsverfahren im landwirtschaftlichen Wasserbau - Chemische Laboruntersuchungen - Bestimmung der Austauschkapazität des Bodens und der austauschbaren Kationen. Deutsches Institut für Normung e.V., Beuth, Berlin.

Djossa BA, Fahr J, Wiegand T, Ayihouenou BE, Kalko EK \& Sinsin BA (2008): Land use impact on Vitellaria paradoxa C.F. Gaerten. stand structure and distribution patterns: a comparison of Biosphere Reserve of Pendjari in Atacora district in Benin. Agrofor Syst 72: 205-220.

Dourma M, Guelly Ka, Kokou K, Batawila K, Wala K, Bellefontaine R \& AKpagana K (2006): Multiplication par drageonnage d'Isoberlinia doka et I. tomentosa au sein des formations arborées du Nord-Togo. Bois Forêts Tropiques 288: 49-57.

Drobnik, J, Roemermann C, Bernhardt-RoEmermann M \& PoschloD P (2011): Adaptation of plant functional group composition to management changes in calcareous grassland. Agric. Ecosyst Environ 145: 29-37.

Duvall CS (2008). Pterocarpus erinaceus Poir. In Louppe D, Oteng-AmoAko AA \& Brink M (eds) Plant Resources of Tropical Africa 7(1). Timbers 1, 478-482. PROTA Founda-tion, Wageningen, NL/Bachhuys Publishers, Leiden.

Erpenbach A, Wittig R \& Hahn K (2014): Dynamics of juvenile woody plant communities on termite mounds in a West African savanna landscape. Flora Veg Sudano-Sambesica 17: 28-41.

FATUBARIN A (1987): Observations on the natural regeneration of the woody plants in a savanna ecosystem in Nigeria. Trop Ecol 28: 1-8.

GAOUE OG \& TickTin T (2008): Impacts of bark and foliage harvest on Khaya senegalensis (Meliaceae) reproductive performance in Benin. J. Appl. Ecol. 45: 34-40.
GARCIA E (2011): A tutorial on correlation coefficients. URL http://www.miislita.com/information-retrieval-tutorial/atutorial-on-correlation-coefficients.pdf.

Gijsberg HJM, Kessler JJ \& Knevel MK (1994): Dynamics and natural regeneration of woody species in farmed parklands in the Sahel region (Province of Passore, Burkina Faso). For. Ecol Manage 64: 1-12.

Glele Kakaï R, Assogbadjo AE, Sinsin B \& Pelz D (2009): Structure spatiale et régénération naturelle de Pterocarpus erinaceus Poir en zone soudanienne au Bénin. Rev. Ivoir Sci Technol. 19: 199-212.

Goldberg DE \& Werner PA (1983): The effects of size of opening in vegetation and litter cover on seedling establishment of Goldenrods (Solidago spp.). Oecol 60: 149-155.

GrÉGoIRE JM \& SimonetTi D (2007): Dynamique des brûlis dans le Parc Régional du W, le Parc National de La Boucle de la Pendjari et la Réserve d'Arly-Implications pour la gestion de ces aires protégées. JRC Sci Techn Res Ser; Office for Official Publications of the European Communities: $1-48$.

GrÉGOIRE JM \& SimonetTi D (2010): Interannual changes of fire activity in the protected areas of the SUN network and other parks and reserves of the West and Central Africa region derived from MODIS observations. Remote Sens 2: 446-463.

GrossniCKLE SC (2005): Importance of root growth in overcoming planting stress. New Forests 30: 273-294.

Gurevich J \& Scheiner SM, Fox GA (2006): Population structure, growth, and decline. In GUREvitch J, SCHEINER SM, Fox GA (eds) The Ecology of Plants, 101-127. Sinauer, Sunderland.

HahN K (1996): Die Pflanzengesellschaften der Savannen im Südosten Burkina Fasos (Westafrika). Ihre Beeinflussung durch den Menschen und die naturräumlichen Gegebenheiten. PhD thesis, University of Frankfurt, Frankfurt.

Hall P \& Bawa K (1993): Methods to assess the impact of extraction of non-timber tropical forest products on plantpopulations. Econ Bot 47: 234-247.

HARPER JL (1977): Population Biology of Plants (1st ed.). Academic Press, London. 892 p.

Higgins SI, Bond WJ \& Trollope WSW (2000): Fire, resprouting and variability: a recipe for grass-tree coexistence in savanna. J. Ecol 88: 213-229.

Hoffmann WA, Orthen B \& Franco AC (2004): Constraints to seedling success of savanna and forest trees across the savanna-forest boundary. Oecol 140: 252-260.

Hothorn T, Bretz F \& Westfall P (2008): Simultaneous inference in general parametric models. Biom J 50: 346363.

JEFFREY DW (1987): Soil-plant relationships: an ecological approach (1st ed). Croom Helm, London. 295 p.

JURENA PN \& ARCHER S (2003): Woody plant establishment and spatial heterogeneity in grasslands. Ecol 84: 907-919.

JuRisch K, Wittig R, Hahn K \& Bernhardt-RömermanN M (2012): Population structure of woody plants in relation to land use in a semi-arid savanna, West Africa. Biotropica 44: 744-751.

JuRisch K, WitTIG R, HAHN K \& BernhaRdT-RÖMERMANN M (2013): Land-use impact on the growth and survival of 
seedlings and saplings in West African savannas. J Veg Sci 24: 101-112.

KAONGA ML \& BAYLISS-SMITH TP (2012): A conceptual model for carbon dynamics for improved fallows in the tropics. 23-44 In KaONGA ML (ed) Agroforestry for Biodiversity and Ecosystem Services - Science and Practice, 101-127. InTech, Rijeka, Croatia

Kelly BA, Hardy OJ \& Bouvet JM (2004): Size class distribution and spatial pattern of Vitellaria paradoxa in relation to farmers' practices in Mali. Agroforest Syst 60: 3-11.

KeSSLER JJ \& BREMAN H (1991): The potential of agroforestry to increase primary production in the Sahelian and Sudanian zones of West Africa. Agroforest Syst 13: 41-62.

KJELDAHL JZ (1883): Neue Methode für die Bestimmung von Stickstoff in organischen Körpern. Z Anal Chem 22 366.

knoema (2013): Household characteristics of Benin 2013.http://knoema.de/BJHC2016/household-characteristics-ofbenin-2013

KNOOP WT \& WALKER BH (1985): Interactions of woody and herbaceous vegetation in a Southern African Savanna. J Ecol 73: 235-253.

KöHN M (1929): Korngrößenanalyse vermittels Pipettanalyse. Tonindustrie-Zeitung 53 729-731.

Kouami K, Yaovi N \& Honan A (2009): Impact of charcoal production on woody plant species in West Africa: A case study in Togo. Sci Res Essays 4: 881-893.

KraAiJ T \& Milton SJ (2006): Vegetation changes (19952004) in semi-arid Karoo shrubland, South Africa: Effects of rainfall, wild herbivores and change in land use. J Arid Environ 64: 174-192.

Ky-Dembele C, Tigabu M, Bayala J, Ouedraogo SJ \& ODEN PC (2007): The relative importance of different regeneration mechanisms in a selectively cut savanna-woodland in Burkina Faso, West Africa. For Ecol Manage 243: 28-38.

Lavorel S, Mcintyre S, Landsberg J \& Forbes TDA (1997): Plant functional classifications: from general groups to specific groups based on response to disturbance. Trends Ecol Evol 12: 474-478.

Luoga EJ, Witkowski ETF \& BALKWILl K (2004): Regeneration by coppicing (resprouting) of miombo (African savanna) trees in relation to land use. For Ecol Manage 189: 23-35.

MAKANA JR \& ThOMAS SC (2006): Impacts of selective logging and agricultural clearing on forest structure, floristic composition and diversity, and timber tree regeneration in the Ituri Forest, Democratic Republic of Congo. Biodivers Conserv 15: 1375-1397.

Mclaren KP, Mccdonald MA, Hall JB \& Healey JR (2005): Predicting species response to disturbance from size class distributions of adults and saplings in a Jamaican tropical dry forest. Plant Ecol 181: 69-84.

Mcnaughton SJ, Wallace LL \& Coughenour MB (1983): Plant adaptation in an ecosystem context - Effects of defoliation, nitrogen, and water on growth of an African C-4 sedge. Ecol 64: 307-318.

Mehlich A (1953): Determination of P, Ca, Mg, K, Na, and $\mathrm{NH}_{4}$. North Carolina Soil Test Division (Mimeo 1953).

MeIwes KJ (1984): Chemische Untersuchungsverfahren zur Charakterisierung und Bewertung der Versauerung in Wald- böden. Ber Forschungszentrum Waldökol 7, Göttingen, 142 p.

Menaut JC (1983): The vegetation of African savannas. In Bourlière F. (ed) Tropical savannas (1st ed.), 109-134. Elsevier, Amsterdam, $730 \mathrm{p}$.

Milton SJ (1995): Spatial and temporal patterns in the emergence and survival of seedlings in arid Karoo shrubland. J Appl Ecol 32: 145-156.

MwaVu EN \& WiTKowski ETF (2009): Seedling regeneration, environment and management in a semi-deciduous African tropical rain forest. J Veg Sci 20: 791-804.

Nacoulma BMi, Schumann K, Traore S, BernhardtRÖMERMANN M, Hahn K, Wittig R \& Thiombiano A (2011): Impacts of land-use on West African savanna vegetation: a comparison between protected and communal area in Burkina Faso. Biodivers Conserv 20: 3341-3362.

NiKiema A (2005): Agroforestry parkland species diversity: uses and management in semi-arid West Africa (Burkina Faso). $\mathrm{PhD}$ thesis, Wageningen University, Wageningen.

Norris K, Asase A, Collen B, Gockowski J, Mason J, Phalan B \& Wade A (2010): Biodiversity in a forest-agriculture mosaic - The changing face of West African rainforests. Biol Conserv 143: 2341-2350.

ORTHMANN B (2005): Vegetation ecology of a woodlandsavanna mosaic in central Benin (West Africa): ecosystem analysis with a focus on the impact of selective logging. $\mathrm{PhD}$ thesis University of Rostock, Rostock.

Orwa C, Mutua A, Kindt R, Jamnadass R \& Simons A (2009): Agroforestree database: a tree species reference and selection guide version 4.0. World Agroforestry Centre ICRAF, Nairobi

Ouedraogo A (2006): Diversité et dynamique de la végétation ligneuse de la partie orientale du Burkina Faso. PhD thesis, University of Ouagadougou, Ouagadougou.

Ouedraogo I, Tigabu M, Savadogo P, Compaore H, Oden PC \& OUADBA JM (2010): Land cover change and its relation with population dynamics in Burkina Faso, West Africa. Land Degrad Dev 21: 453-462.

OYen LPA (2011): Bombax costatum Pellegr. \& Vuillet. (Internet) Record from PROTA4U. In BRINK M \& ACHIGANDAKo EG (eds) PROTA (Plant Resources of Tropical Africa / Ressources végétales de l'Afrique tropicale), Wageningen. URL http://www.prota4u.org/search.asp.

Pare S, Savadogo P, Tigabu M, Oden PC \& Ouadba JM (2009): Regeneration and spatial distribution of seedling populations in Sudanian dry forests in relation to conservation status and human pressure. Trop Ecol 50: 339-353.

Peters CM (1990): Population ecology and management of forest fruit trees in Peruvian Amazoniain. In ANDERSON $\mathrm{AB}$ (ed) Alternatives to deforestation: Steps toward sustainable use of the amazon rain forest (1st ed.), 86-90. Columbia Univ. Press, New York.

Plumptre AJ (1995): The importance of 'seed trees' for the natural regeneration of selectively logged tropical forest. Commonw Forest Rev 74: 253-258.

Pretzsch H (2002): Grundlagen der Waldwachstumsforschung. Parey, Berlin. 448 p.

Prior LD, Williams RJ \& Bowmann DMJS (2010): Experimental evidence that fire causes a tree recruitment bottleneck in an Australian tropical savanna. J Trop Ecol 26: 595-603. 
Pulido FJ \& DiAz M (2005): Regeneration of a Mediterranean oak: A whole-cycle approach. Ecosci 12: 92-102.

R Development Core Team (2011): R: A language and environment for statistical computing. R Foundation for Statistical Computing, Vienna, Austria.

Riginos C (2009): Grass competition suppresses savanna tree growth across multiple demographic stages. Ecol 90: 335-340.

SACANDE M \& SANOGo S (2007): Anogeissus leiocarpus (DC.) Guill. \& Perr. Seed Leaflet 109.

Sankaran M, Ratnam J \& Hanan N (2008): Woody cover in African savannas: the role of resources, fire and herbivory. Glob Ecol Biogeogr 17: 236-245.

Schmidt M \& ZizKa G (2014): Plant species associated with different levels of species richness and of vegetation cover as indicators of desertification in Burkina Faso (West Africa). Flora Veg Sudano-Sambesica 17: 3-8.

SCHOLES R.J \& ARCher SR (1997): Tree-grass interactions in savannas. Ann Rev Ecol Evol Syst 28: 517-544.

SCHÜLLER H (1969): Die CAL-Methode, eine neue Methode zur Bestimmung des pflanzen-verfügbaren Phosphates in Böden. Z Pflanzenernährung Bodenkunde 123: 63-48.

SCHÜLLER H (1973): Über die Untersuchung von Böden mit hohen Carbonatgehalten. Landwirt. Forsch 26, Sonderheft 28/1: 140-155.

Schumann K, Wittig R, Thiombiano A, Becker U \& HAHN K (2011): Impact of land-use type and harvesting on population structure of a non-timber forest product-providing tree in a semi-arid savanna, West Africa. Biol Conserv 144: $2369-2376$.

Silvertown J \& Smith B (1989): Germination and population structure of spear thistle Cirsium vulgare in relation to experimentally controlled sheep grazing. Oecol 81: 369373.

Staver AC, Bond WJ, Stock WD, Van Rensburg SJ \& WALDRAM MS (2009): Browsing and fire interact to suppress tree density in an African savanna. Ecol Appl 19: 1909-1919.

SUN - Tools For Management and Sustainable Use of Natural vegetation in West Africa (2010): Periodic Activity Report. unpubl.

SwAINE MD (1996): Rainfall and soil fertility as factors limiting forest species distributions in Ghana. J Ecol 84: 419428.

TICKTIN T (2004): The ecological implications of harvesting non-timber forest products. J Appl Ecol 41: 11-21.
VANAUKEN OW \& BUSH JK (1997): The importance of neighbors, soil $\mathrm{pH}$, phosphorus, and nitrogen for the growth of two C-4 grasses. Int J Plant Sci 158: 325-331.

Van Der Waal C, De Kroon H, De Boer WF, HeitkoeNig IM, Skidmore AK, De Knegt HJ, Van Langevelde F, Van Wieren SE, Grant RC, Page BR, Slotow R, Kohi EM, Mwakiwa E \& Prins HH (2009): Water And Nutrients Alter Herbaceous Competitive Effects On Tree Seedlings In A Semi-Arid Savanna. J Ecol 97: 430-439.

Van Der Waal C, Kool A, Meijer SS, Kohi E, Heitkönig IM, De Boer WF, Van Langevelde F, Grant RC, Peel MJ, Slotow R, De Knegt HJ, Prins HH \& De Kroon H (2011): Large herbivores may alter vegetation structure of semi-arid savannas through soil nutrient mediation. Oecol 165: 1095-1107.

Vanderberghe C, Frelechoux F, Gadallah F \& Buttler A (2006): Competitive effects of herbaceous vegetation on tree seedling emergence, growth and survival: Does gap size matter? J Veg Sci17: 481-488.

Walker BH, Ludwig D, Holling CS, Petermann RM (1981): Stability of Semi-Arid Savanna Grazing Systems. J Ecol 69: 473-498.

WeLtZIN JF \& MCPHERSON GR (1997): Spatial and temporal soil moisture resource partitioning by trees and grasses in a temperate savanna, Arizona, USA. Oecol 112:156-164.

Wigley BJ, Cramer MD \& Bond WJ (2009): Sapling survival in a frequently burnt savanna: mobilisation of carbon reserves in Acacia karroo. Plant Ecol. 203: 1-11.

Wittig R, Hahn K, Krohmer J, Müller J \& Sieglstetter R (2002): La végétation actuelle des savannes du Burkina Faso et du Benin - sa signification pour l'homme et la modification de celle-ci par l'homme (apercu des résultats d'un projet de recherche duré des années).- Etudes flor vég Burkina Faso 7: 3-16.

ZIDA D (2007): Impacts of forest management regimes of ligneous regeneration in the Sudanian savanna of Burkina Faso. $\mathrm{PhD}$ thesis, Umeå University, Umeå.

Zida D, Sawadogo L, Tigabu M, Tiveau D \& Oden PC (2007): Dynamics of sapling population in savanna woodlands of Burkina Faso subjected to grazing, early fire and selective tree cutting for a decade. For Ecol Manage 243: 102-115.

Zida D, Tigabu M, Sawadogo L \& Oden PC (2008): Initial seedling morphological characteristics and field performance of two Sudanian savanna species in relation to nursery production period and watering regimes. For Ecol Manage 255: 2151-2162. 


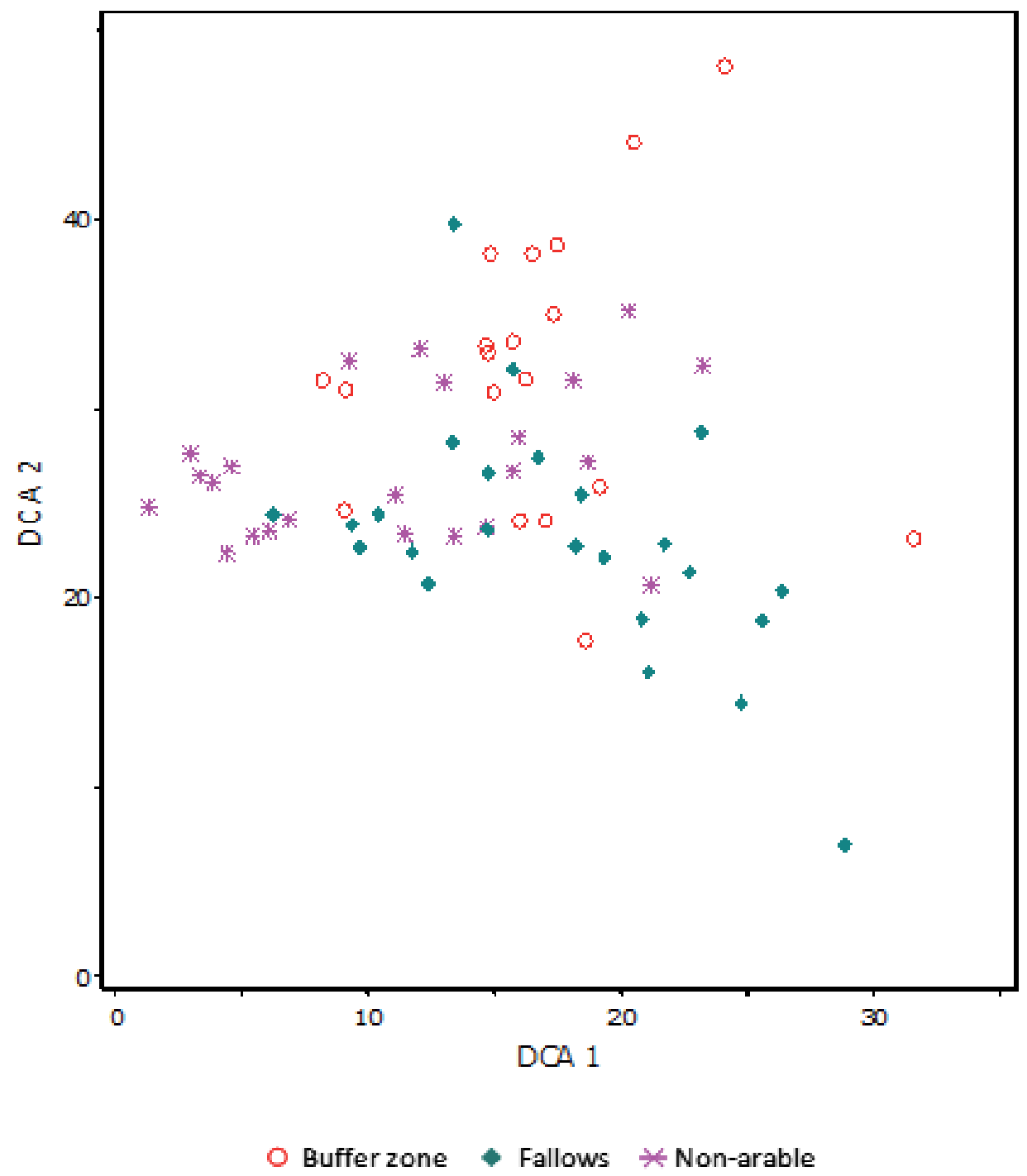

Appendix 1: DCA plot of the vegetation of non-arable sites, fallows and the buffer zone, based on the species cover of woody plants of the woody layers. The ordination was based on 130 species in 66 plots ( 23 on non-arable sites, 24 in fallows, 19 in the buffer zone), length of first axis 2.5 , explained variance: $9.3 \%$, second axis: $6.8 \%$ explained variance.

In order to reveal similarities or differences in vegetation composition between the three land-cover types, we used detrended correspondence analysis (DCA), as this technique provides eigenvalues that allow estimation of gradient length as a measure of variation between samples (HILL \& GAUCH 1980). Prior to analyses, vegetation data were arcsine-squareroot-transformed. The results of this analysis are presented in Appendix 3 and clearly show that the studied land-cover types were comparable with respect to their vegetation composition. / DCA plot de la végétation des sites non arables, des jachères et la zone tampon, sur la base de la couverture des espèces de plantes ligneuses des couches ligneuses. L'ordination était basée sur 130 espèces réparties sur 66 parcelles (23 sur les terres non arables, 24 sur les jachères, 19 dans la zone tampon), longueur du premier axe 2.5, variance expliquée: 9.3\%, deuxième axe: $6.8 \%$ de la variance expliquée.

Afin de révéler des similitudes ou des différences de composition végétale entre les trois types de couvert végétal, nous avons utilisé l'analyse de correspondance détruits (DCA), car cette technique fournit des valeurs propres qui permettent d'estimer la longueur du gradient comme mesure de variation entre les échantillons (HILL ET GAUCH 1980). Avant les analyses, les données sur la végétation étaient transformées en arcsine-squareroot. Les résultats de cette analyse sont présentés dans l'annexe 3 et montrent clairement que les types de couvert végétal étudiés étaient comparables par rapport à leur composition végétale. 
Appendix 2: $\quad$ Pearson correlation coefficients (r) between physical and chemical characteristics of soil from 39 study sites, those variables with a strong intercorrelation ( $\mathrm{r}> \pm 0.7$ ) were highlighted a star. / Coefficients de corrélation de Pearson (r) entre les caractéristiques physiques et chimiques du sol des 39 sites d'étude, les variables ayant une forte corrélation $(r> \pm 0,7)$ ont été mises en évidence par une étoile.

\begin{tabular}{|c|c|c|c|c|}
\hline Parameter 1 & Parameter 2 & $\mathbf{r}$ & F-value & P-value \\
\hline Height herb layer $(\mathrm{cm})$ & Cover tree/shrub layer (\%) & -0.4345 & -2.932 & 0.006 \\
\hline Height herb layer $(\mathrm{cm})$ & Cover herb layer $(\%)$ & 0.560 & 4.115 & 0.000 \\
\hline Height herb layer $(\mathrm{cm})$ & $\mathrm{pH}$ & 0.382 & 2.513 & 0.016 \\
\hline Height herb layer $(\mathrm{cm})$ & $\mathrm{K}^{+}(\mathrm{mmolc} / \mathrm{kg})$ & 0.433 & 2.923 & 0.006 \\
\hline Height herb layer (cm) & CECpot $(\mathrm{cmolc} / \mathrm{kg})$ & -0.476 & -3.296 & 0.002 \\
\hline Height herb layer (cm) & BS-value & 0.547 & 3.973 & 0.000 \\
\hline Height herb layer $(\mathrm{cm})$ & Coarse silt (\%) & 0.526 & 3.760 & 0.000 \\
\hline Height herb layer $(\mathrm{cm})$ & Medium silt (\%) & -0.055 & -0.337 & 0.738 \\
\hline Height herb layer $(\mathrm{cm})$ & Clay $<2 \mu \mathrm{m}(\%)$ & -0.641 & -5.075 & $1.12 * 10^{-5}$ \\
\hline Height herb layer (cm) & $\mathrm{K}_{2} \mathrm{O}(\mathrm{mg} / 100 \mathrm{~g})$ & 0.038 & 0.231 & 0.819 \\
\hline Cover tree/shrub layer $(\%)$ & Cover herb layer $(\%)$ & -0.440 & -2.980 & 0.005 \\
\hline Cover tree/shrub layer $(\%)$ & $\mathrm{pH}$ & -0.300 & -1.904 & 0.065 \\
\hline Cover tree/shrub layer $(\%)$ & $\mathrm{K}^{+}(\mathrm{mmolc} / \mathrm{kg})$ & -0.354 & -2.303 & 0.0270 \\
\hline Cover tree/shrub layer $(\%)$ & CECpot (cmolc/kg) & 0.610 & 4.682 & $3.75^{*} 10^{-5}$ \\
\hline Cover tree/shrub layer ( $\%)$ & BS-value & -0.549 & -3.995 & 0.000 \\
\hline Cover tree/shrub layer $(\%)$ & Coarse silt (\%) & -0.329 & -2.118 & 0.041 \\
\hline Cover tree/shrub layer $(\%)$ & Medium silt (\%) & 0.040 & 0.242 & 0.810 \\
\hline Cover tree/shrub layer $(\%)$ & Clay $<2 \mu \mathrm{m}(\%)$ & 0.523 & 3.734 & 0.000 \\
\hline Cover tree/shrub layer (\%) & $\mathrm{K}_{2} \mathrm{O}(\mathrm{mg} / 100 \mathrm{~g})$ & -0.191 & -1.181 & 0.245 \\
\hline Cove herb layer (\%) & $\mathrm{pH}$ & 0.326 & 2.096 & 0.043 \\
\hline Cove herb layer $(\%)$ & $\mathrm{K}^{+}(\mathrm{mmolc} / \mathrm{kg})$ & 0.297 & 1.894 & 0.066 \\
\hline Cove herb layer (\%) & CECpot (cmolc/kg) & -0.637 & -5.029 & $1.29 * 10^{-5}$ \\
\hline Cove herb layer $(\%)$ & BS-value & 0.598 & 4.540 & $5.78 * 10^{-5}$ \\
\hline Cove herb layer (\%) & Coarse silt (\%) & 0.473 & 3.270 & 0.002 \\
\hline Cove herb layer (\%) & Medium silt (\%) & -0.155 & -0.957 & 0.345 \\
\hline Cove herb layer (\%) & Clay $<2 \mu \mathrm{m}(\%)$ & -0.609 & -4.668 & $3.92 * 10^{-5}$ \\
\hline Cove herb layer (\%) & $\mathrm{K}_{2} \mathrm{O}(\mathrm{mg} / 100 \mathrm{~g})$ & 0.021 & 0.130 & 0.897 \\
\hline pH & $\mathrm{K}^{+}(\mathrm{mmolc} / \mathrm{kg})$ & 0.536 & 3.867 & 0.000 \\
\hline pH & CECpot (cmolc/kg) & -0.208 & -1.293 & 0.204 \\
\hline pH & BS-value & 0.610 & 4.679 & $3.78 * 10^{-5}$ \\
\hline pH & Coarse silt (\%) & -0.128 & -0.785 & 0.438 \\
\hline pH & Medium silt (\%) & -0.237 & -1.486 & 0.146 \\
\hline pH & Clay $<2 \mu \mathrm{m}(\%)$ & -0.245 & -1.539 & 0.132 \\
\hline pH & $\mathrm{K}_{2} \mathrm{O}(\mathrm{mg} / 100 \mathrm{~g})$ & 0.442 & 2.996 & 0.005 \\
\hline $\mathrm{K}^{+}(\mathrm{mmolc} / \mathrm{kg})$ & CECpot $(\mathrm{cmolc} / \mathrm{kg})$ & -0.209 & -1.303 & 0.201 \\
\hline $\mathrm{K}^{+}$(mmolc/kg) & BS-value & 0.559 & 4.103 & 0.000 \\
\hline $\mathrm{K}^{+}$(mmolc/kg) & Coarse silt (\%) & -0.182 & -1.129 & 0.266 \\
\hline $\mathrm{K}^{+}(\mathbf{m m o l c} / \mathrm{kg})$ & Medium silt (\%) & -0.139 & -0.853 & 0.399 \\
\hline $\mathrm{K}^{+}$(mmolc/kg) & Clay $<2 \mu \mathrm{m}(\%)$ & -0.0689 & -0.413 & 0.682 \\
\hline $\mathrm{K}^{+}(\mathrm{mmolc} / \mathrm{kg}) *$ & $\mathrm{~K}_{2} \mathrm{O}(\mathrm{mg} / 100 \mathrm{~g})$ & 0.785 & 7.709 & $3.29 * 10^{-9}$ \\
\hline CECpot (cmolc/kg)* & BS-value & -0.783 & -7.663 & $3.77 * 10^{-9}$ \\
\hline CECpot (cmolc/kg) & Coarse silt (\%) & -0.426 & -2.861 & 0.007 \\
\hline CECpot (cmolc/kg) & Medium silt (\%) & 0.316 & 2.024 & 0.050 \\
\hline CECpot (cmolc/kg) & Clay $<2 \mu \mathrm{m}(\%)$ & 0.574 & 4.269 & 0.000 \\
\hline CECpot (cmolc/kg) & $\mathrm{K}_{2} \mathrm{O}(\mathrm{mg} / 100 \mathrm{~g})$ & 0.013 & 0.082 & 0.935 \\
\hline BS-value & Coarse silt (\%) & 0.152 & 0.939 & 0.354 \\
\hline BS-value & Medium silt (\%) & -0.319 & -2.045 & 0.048 \\
\hline BS-value & Clay $<2 \mu \mathrm{m}(\%)$ & -0.424 & -2.851 & 0.007 \\
\hline BS-value & $\mathrm{K}_{2} \mathrm{O}(\mathrm{mg} / 100 \mathrm{~g})$ & 0.330 & 2.052 & 0.047 \\
\hline Coarse silt (\%) & Medium silt (\%) & 0.235 & 1.468 & 0.151 \\
\hline Coarse silt (\%) & Clay $<2 \mu \mathrm{m}(\%)$ & -0.500 & -3.509 & 0.001 \\
\hline Coarse silt (\%) & $\mathrm{K}_{2} \mathrm{O}(\mathrm{mg} / 100 \mathrm{~g})$ & -0.415 & -2.776 & 0.009 \\
\hline Medium silt (\%) & Clay $<2 \mu \mathrm{m}(\%)$ & 0.249 & 1.567 & 0.126 \\
\hline Medium silt (\%) & $\mathrm{K}_{2} \mathrm{O}(\mathrm{mg} / 100 \mathrm{~g})$ & -0.237 & -1.486 & 0.146 \\
\hline Clay $<2 \mu \mathrm{m}(\%)$ & Clay < $2 \mu \mathrm{m}(\%)$ & 0.141 & 0.868 & 0.391 \\
\hline
\end{tabular}


Appendix 3: Juvenile densities $\left(100 \mathrm{~m}^{2}\right)$ of the 25 analyzed woody species. Densities are presented according to species group affiliation, land cover type and census (plots sampled on non-arable land: $n=12$, fallow: $n=17$ and buffer zone: $n=10$ ). Similarity between landcover types concerning the juvenile densities, calculated by a linear-mixed-effect model and a subsequent Tukey's multiple comparison test, is marked by $(\&)$, dissimilarity by $(\neq)$. / Densités juvéniles $\left(100 \mathrm{~m}^{2}\right)$ des 25 espèces ligneuses analysées. Les densités sont présentées selon l'appartenance au groupe d'espèces, le type de couverture et le recensement (parcelles échantillonnées sur les terres non arables: $\mathrm{n}=12$, jachère: $\mathrm{n}=17$ et zone tampon: $\mathrm{n}=10$ ). La similarité entre les types de couvert végétal concernant les densités juvéniles, calculée par un modèle à effet mixte linéaire et un essai de comparaison multiple de Tukey subséquent, est indiquée par $(\&)$, dissimilarité par $(\neq)$.

\begin{tabular}{|c|c|c|c|c|c|c|c|c|}
\hline \multirow[t]{2}{*}{ Life form } & \multirow[t]{2}{*}{ Family } & \multirow[t]{2}{*}{ Species } & \multirow{2}{*}{$\begin{array}{c}\text { May } 2008 \\
\text { non- } \\
\text { arable }\end{array}$} & \multicolumn{5}{|c|}{ Oct 2008} \\
\hline & & & & fallows & $\begin{array}{c}\text { buffer } \\
\text { zone }\end{array}$ & $\begin{array}{c}\text { non- } \\
\text { arable }\end{array}$ & fallows & $\begin{array}{l}\text { buffer } \\
\text { zone }\end{array}$ \\
\hline \multicolumn{9}{|c|}{ Group A: non-arable $\neq$ fallows $\neq$ buffer zone } \\
\hline tree & Fabaceae & Pterocarpus erinaceus. & 24 & 24 & 32 & 36 & 32 & 60 \\
\hline \multicolumn{9}{|c|}{ Group B: non-arable \& fallows $\neq$ buffer zone } \\
\hline shrub & Annonaceae & Annona senegalensis. & 40 & 148 & 0 & 64 & 160 & 0 \\
\hline shrub & Rubiaceae & Crossopteryx febrifuga & 28 & 36 & 40 & 28 & 28 & 40 \\
\hline tree & Anacardiaceae & Lannea acida A.Rich. & 24 & 48 & 0 & 24 & 52 & 0 \\
\hline tree & Combretaceae & Terminalia avicennioides & 28 & 120 & 8 & 52 & 128 & 8 \\
\hline \multicolumn{9}{|c|}{ Group C: non-arable \& buffer zone $\neq$ fallows } \\
\hline shrub & Mimosaceae & Acacia hockii & 0 & 36 & 4 & 0 & 36 & 4 \\
\hline tree & Combretaceae & Anogeissus leiocarpa & 8 & 52 & 8 & 8 & 68 & 8 \\
\hline shrub & Combretaceae & Combretum collinum & 72 & 360 & 40 & 76 & 376 & 56 \\
\hline shrub & Mimosaceae & Dichrostachys cinerea & 184 & 696 & 20 & 228 & 732 & 20 \\
\hline shrub & Ebenaceae & Diospyros mespiliformis & 0 & 124 & 4 & 0 & 132 & 4 \\
\hline shrub & Rubiaceae & Feretia apodanthera & 8 & 180 & 4 & 8 & 180 & 4 \\
\hline shrub & Rubiaceae & Gardenia ternifolia & 36 & 44 & 20 & 44 & 36 & 28 \\
\hline shrub & Caesalpiniaceae & Piliostigma thonningii & 16 & 120 & 4 & 20 & 128 & 8 \\
\hline shrub & Strychnaceae & Strychnos spinosa & 32 & 38 & 72 & 68 & 80 & 96 \\
\hline tree & Sapotaceae & Vitellaria paradoxa & 56 & 168 & 12 & 62 & 224 & 24 \\
\hline \multicolumn{9}{|c|}{ Group D: fallows \& buffer zone $\neq$ non-arable } \\
\hline shrub & Combretaceae & Combretum glutinosum & 36 & 16 & 4 & 44 & 12 & 4 \\
\hline shrub & Combretaceae & Combretum nigricans & 144 & 92 & 16 & 156 & 84 & 16 \\
\hline shrub & Caesalpiniaceae & Detarium microcarpum & 628 & 128 & 0 & 816 & 128 & 0 \\
\hline tree & Caesalpiniaceae & Isoberlinia doka & 8 & 88 & 32 & 12 & 104 & 60 \\
\hline tree & Fabaceae & Philenoptera laxiflora & 4 & 56 & 24 & 0 & 60 & 28 \\
\hline shrub & Combretaceae & Pteleopsis suberosa & 408 & 212 & 0 & 416 & 204 & 4 \\
\hline tree & Bignoniaceae & Stereospermum kunthianum & 136 & 136 & 20 & 192 & 128 & 52 \\
\hline \multicolumn{9}{|c|}{ Group E: non-arable \& fallows \& buffer zone } \\
\hline tree & Bombacaceae & Bombax costatum & 4 & 20 & 12 & 8 & 20 & 12 \\
\hline shrub & Combretaceae & Combretum molle & 84 & 124 & 76 & 112 & 144 & 92 \\
\hline shrub & Rubiaceae & Gardenia aqualla & 8 & 16 & 16 & 4 & 28 & 12 \\
\hline
\end{tabular}


Appendix 3 (continued).

\begin{tabular}{|c|c|c|c|c|c|c|c|c|c|c|c|}
\hline \multirow[t]{2}{*}{ Life form } & \multirow[t]{2}{*}{ Family } & \multirow[t]{2}{*}{ Species } & \multicolumn{3}{|c|}{ May 2009} & \multicolumn{3}{|c|}{ Oct 2009} & \multicolumn{3}{|c|}{ May 2010} \\
\hline & & & $\begin{array}{l}\text { non- } \\
\text { ara- } \\
\text { ble }\end{array}$ & $\begin{array}{l}\text { fal- } \\
\text { lows }\end{array}$ & $\begin{array}{l}\text { buf- } \\
\text { fer } \\
\text { zone }\end{array}$ & $\begin{array}{l}\text { non- } \\
\text { ara- } \\
\text { ble }\end{array}$ & $\begin{array}{l}\text { fal- } \\
\text { lows }\end{array}$ & $\begin{array}{l}\text { buf- } \\
\text { fer } \\
\text { zone }\end{array}$ & $\begin{array}{l}\text { non- } \\
\text { ara- } \\
\text { ble }\end{array}$ & $\begin{array}{l}\text { fal- } \\
\text { lows }\end{array}$ & $\begin{array}{l}\text { buf- } \\
\text { fer } \\
\text { zone }\end{array}$ \\
\hline \multicolumn{12}{|c|}{ Group A: non-arable $\neq$ fallows $\neq$ buffer zone } \\
\hline tree & Fabaceae & Pterocarpus erinaceus & 44 & 24 & 80 & 52 & 36 & 92 & 52 & 36 & 72 \\
\hline \multicolumn{12}{|c|}{ group B: non-arable \& fallows $\neq$ buffer zone } \\
\hline shrub & Annonaceae & Annona senegalensis & 68 & 164 & 0 & 84 & 204 & 4 & 140 & 252 & 0 \\
\hline shrub & Rubiaceae & Crossopteryx febrifuga & 28 & 28 & 40 & 28 & 28 & 40 & 28 & 24 & 40 \\
\hline tree & Anacardiaceae & Lannea acida A.Rich. & 48 & 104 & 8 & 64 & 148 & 0 & 76 & 184 & 8 \\
\hline tree & Combretaceae & Terminalia avicennioides & 76 & 132 & 20 & 88 & 152 & 28 & 88 & 200 & 28 \\
\hline \multicolumn{12}{|c|}{ Group C: non-arable \& buffer zone $\neq$ fallows } \\
\hline shrub & Mimosaceae & Acacia hockii & 0 & 40 & 4 & 0 & 48 & 4 & 0 & 36 & 4 \\
\hline tree & Combretaceae & Anogeissus leiocarpa & 76 & 292 & 20 & 56 & 272 & 36 & 104 & 496 & 36 \\
\hline shrub & Combretaceae & Combretum collinum & 72 & 384 & 52 & 92 & 444 & 64 & 104 & 424 & 64 \\
\hline shrub & Mimosaceae & Dichrostachys cinerea & 240 & 648 & 20 & 256 & 668 & 28 & 252 & 608 & 32 \\
\hline shrub & Ebenaceae & Diospyros mespiliformis & 4 & 172 & 4 & 4 & 188 & 4 & 4 & 196 & 4 \\
\hline shrub & Rubiaceae & Feretia apodanthera & 16 & 216 & 4 & 16 & 228 & 4 & 16 & 220 & 4 \\
\hline shrub & Rubiaceae & Gardenia ternifolia & 36 & 40 & 24 & 44 & 36 & 28 & 44 & 36 & 24 \\
\hline shrub & Caesalpiniaceae & Piliostigma thonningii & 28 & 112 & 8 & 28 & 132 & 8 & 24 & 148 & 8 \\
\hline shrub & Strychnaceae & Strychnos spinosa & 60 & 56 & 96 & 92 & 88 & 120 & 72 & 88 & 120 \\
\hline tree & Sapotaceae & Vitellaria paradoxa & 80 & 268 & 20 & 84 & 82 & 328 & 80 & 292 & 32 \\
\hline \multicolumn{12}{|c|}{ Group D: fallows \& buffer zone $\neq$ non-arable } \\
\hline shrub & Combretaceae & Combretum glutinosum & 40 & 12 & 8 & 48 & 12 & 8 & 44 & 12 & 8 \\
\hline shrub & Combretaceae & Combretum nigricans. & 164 & 108 & 20 & 192 & 108 & 20 & 204 & 112 & 20 \\
\hline shrub & Caesalpiniaceae & Detarium microcarpum & 824 & 132 & 0 & 1028 & 136 & 0 & 948 & 152 & 0 \\
\hline tree & Caesalpiniaceae & Isoberlinia doka & 12 & 120 & 64 & 36 & 176 & 96 & 44 & 156 & 56 \\
\hline tree & Fabaceae & Philenoptera laxiflora & 0 & 52 & 40 & 4 & 64 & 96 & 0 & 60 & 76 \\
\hline shrub & Combretaceae & Pteleopsis suberosa & 384 & 200 & 4 & 424 & 224 & 4 & 8 & 220 & 8 \\
\hline tree & Bignoniaceae & Stereospermum kunthianum & 164 & 116 & 48 & 188 & 140 & 76 & 192 & 144 & 68 \\
\hline \multicolumn{12}{|c|}{ Group E: non-arable \& fallows \& buffer zone } \\
\hline tree & Bombacaceae & Bombax costatum & 12 & 16 & 8 & 32 & 36 & 24 & 20 & 44 & 12 \\
\hline shrub & Combretaceae & Combretum molle & 136 & 212 & 88 & 156 & 232 & 136 & 140 & 268 & 212 \\
\hline shrub & Rubiaceae & Gardenia aqualla & 8 & 28 & 12 & 8 & 32 & 16 & 8 & 32 & 16 \\
\hline
\end{tabular}

